\title{
Greenhouse gas emissions from the grassy outdoor run of organic broilers
}

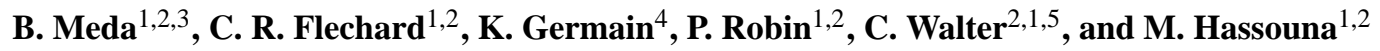 \\ ${ }^{1}$ INRA, UMR1069 Sol Agro et hydrosystème Spatialisation, 35000 Rennes, France \\ ${ }^{2}$ Agrocampus Ouest, 35000 Rennes, France \\ ${ }^{3}$ INRA, UR83 Recherches Avicoles, 37380 Nouzilly, France \\ ${ }^{4}$ INRA, UE1206 Élevage alternatif et santé des monogastriques, Domaine du Magneraud, \\ 17700 Saint-Pierre-d'Amilly, France \\ ${ }^{5}$ Université Européenne de Bretagne, Rennes, France
}

Correspondence to: C. R. Flechard (chris.flechard@ rennes.inra.fr)

Received: 15 November 2011 - Published in Biogeosciences Discuss.: 30 November 201

Revised: 2 April 2012 - Accepted: 3 April 2012 - Published: 20 April 2012

\begin{abstract}
Nitrous oxide $\left(\mathrm{N}_{2} \mathrm{O}\right)$, methane $\left(\mathrm{CH}_{4}\right)$ and carbon dioxide $\left(\mathrm{CO}_{2}\right)$ fluxes over the grassy outdoor run of organically grown broilers were monitored using static chambers over two production batches in contrasted seasons. Measured $\mathrm{N}_{2} \mathrm{O}$ and $\mathrm{CH}_{4}$ fluxes were extremely variable in time and space for both batches, with fluxes ranging from a small uptake by soil to large emissions peaks, the latter of which always occurred in the chambers located closest to the broiler house. In general, fluxes decreased with increasing distance to the broiler house, demonstrating that the foraging of broilers and the amount of excreted nutrients (carbon, nitrogen) largely control the spatial variability of emissions. Spatial integration by kriging methods was carried out to provide representative fluxes on the outdoor run for each measurement day. Mechanistic relationships between plot-scale estimates and environmental conditions (soil temperature and water content) were calibrated in order to fill gaps between measurement days. Flux integration over the year 2010 showed that around $3 \pm 1 \mathrm{~kg} \mathrm{~N}_{2} \mathrm{O}-\mathrm{Nha}^{-1}$ were emitted on the outdoor run, equivalent to $0.9 \%$ of outdoor $\mathrm{N}$ excretion and substantially lower than the IPCC default emission factor of $2 \%$. By contrast, the outdoor run was found to be a net $\mathrm{CH}_{4}$ sink of about $-0.56 \mathrm{~kg} \mathrm{CH}_{4}-\mathrm{Cha}^{-1}$, though this sink compensated less than $1.5 \%$ (in $\mathrm{CO}_{2}$ equivalents) of $\mathrm{N}_{2} \mathrm{O}$ emissions. The net greenhouse gas (GHG) budget of the outdoor run is explored, based on measured GHG fluxes and shortterm $(1.5 \mathrm{yr})$ variations in soil organic carbon.
\end{abstract}

\section{Introduction}

Carbon dioxide $\left(\mathrm{CO}_{2}\right)$, nitrous oxide $\left(\mathrm{N}_{2} \mathrm{O}\right)$ and methane $\left(\mathrm{CH}_{4}\right)$ are among the most important greenhouse gases (GHG) responsible for climate change (IPCC, 2007b), and $\mathrm{N}_{2} \mathrm{O}$ also contributes to stratospheric ozone depletion (Ravishankara et al., 2009). Climate change is one of the most challenging environmental issues of the 21 st century (UNFCCC, 2009) and solutions must be found in order to mitigate GHG emissions on a global scale. Agriculture contributes $13.5 \%$ of global anthropogenic GHG emissions (expressed in $\mathrm{CO}_{2}$ equivalents, $\mathrm{CO}_{2}$ eq.) (IPCC, 2007a), and livestock production is known to be a major emitter of GHG with $9 \%$ of total $\mathrm{CO}_{2}$ eq. emissions (FAO, 2006).

In poultry production, GHG are mainly emitted by manure in houses, in storage facilities or during and after field application of manure. In comparison with cattle production, which accounts for $23 \%$ of total $\mathrm{N}_{2} \mathrm{O}$ emissions and more than $15 \%$ of total $\mathrm{CH}_{4}$ emissions in France, poultry production is responsible for relatively little GHG emission, i.e. about $1.5 \%$ of total $\mathrm{N}_{2} \mathrm{O}$ emissions and $2.2 \%$ of total $\mathrm{CH}_{4}$ emissions (Gac et al., 2007). Nevertheless, few data concerning GHG emissions from poultry rearing systems are available and uncertainties on emission factors are high (Meda et al., 2011). 
This lack of knowledge is even larger for alternative, less intensive rearing systems, which provide an outdoor access to the animals (free-range and/or organic farming). In these systems, a fraction of droppings is excreted onto an outdoor run (called "run" hereafter), leading to gaseous emissions on the run as well as in the house, due to microbial processes occurring in the soil and in the litter. Estimates of GHG and ammonia emissions from organic broiler houses were proposed by Meda (2011) but outdoor emissions also need to be quantified. To our knowledge, there is no study concerning outdoor GHG emissions from poultry in the literature. Nonetheless, the general mechanisms regulating emissions are known. $\mathrm{N}_{2} \mathrm{O}$ is widely believed to be emitted as a by-product of the oxidation of ammonium $\left(\mathrm{NH}_{4}^{+}\right)$to nitrite $\left(\mathrm{NO}_{2}^{-}\right)$and to nitrate $\left(\mathrm{NO}_{3}^{-}\right)$(nitrification), and of the reduction of $\mathrm{NO}_{3}^{-}$ultimately to $\mathrm{N}_{2}$ (denitrification), the latter becoming dominant with increasing soil moisture (Davidson, 1991; Smith et al., 2003), and thus $\mathrm{N}_{2} \mathrm{O}$ can be released on the run under favourable conditions. Droppings excreted on the run indeed add biodegradable carbon (C), available nitrogen (ammonium, uric acid) and moisture to the soil, thereby enhancing nitrification and/or denitrification processes and thus $\mathrm{N}_{2} \mathrm{O}$ emissions (Smith et al., 2003). $\mathrm{CH}_{4}$ is produced by the microbial degradation in anaerobic conditions of organic matter found in droppings and soil (Le Mer and Roger, 2001; Smith et al., 2003) but under well aerated conditions $\mathrm{CH}_{4}$ is also often oxidized (consumed) by agricultural soils (Smith et al., 2000; Le Mer and Roger, 2001; Castaldi et al., 2007). The interplay of all these different processes makes the prediction of net $\mathrm{N}_{2} \mathrm{O}$ and $\mathrm{CH}_{4}$ fluxes a difficult exercise.

In this paper, we present the results of GHG flux measurements $\left(\mathrm{N}_{2} \mathrm{O}, \mathrm{CH}_{4}\right.$ and $\left.\mathrm{CO}_{2}\right)$ over a period of $1 \mathrm{yr}$ over a sown grassland, which served as the run for organic broilers, as part of the French AlterAviBio project. The study was conducted on two broiler batches, reared in winter/spring 20092010 and in summer/autumn 2010, providing a range of climatic and environmental conditions known to control GHG emissions. The study also focuses on broiler behaviour as a factor controlling the spatial and temporal variability of GHG fluxes. The measurements are used to provide annual emission fluxes, which for $\mathrm{N}_{2} \mathrm{O}$ are also expressed as emission factors (EF) as the percentage of emission relative to the $\mathrm{N}$ input to the run (Pain and Menzi, 2011), and to estimate the net GHG exchange (NGHGE) of the run.

\section{Materials and methods}

\subsection{Study site characteristics}

The study took place on the experimental facility of the French National Institute for Agricultural Research (INRA) at Le Magneraud (Long. $00^{\circ} 41^{\prime} 25^{\prime \prime} \mathrm{W}$, Lat. $46^{\circ} 09^{\prime} 04^{\prime \prime} \mathrm{N}$ ) at an altitude of $60 \mathrm{~m}$ above mean sea level. The climate in the region is temperate oceanic with an interannual mean air temperature of around $12{ }^{\circ} \mathrm{C}$ and mean annual precipitation of around $780 \mathrm{~mm}$. The soil is a clay loam and moderately alkaline ( $\mathrm{pH}$ about 8.2). It is morphologically simple, consisting of an A horizon (25-35 cm thick) with about $15 \%$ of limestone coarse elements (from a few millimetres to a few centimetres) above a $\mathrm{C}$ horizon (rendzicleptosol (calcaric)). The upper layer $(0-15 \mathrm{~cm})$ is rich in organic carbon $(2.45 \%)$, with a $\mathrm{C} / \mathrm{N}$ ratio of about 9.7 . Before 2008 , the field was used for crop production (maize, winter wheat, sunflower and winter pea) before being converted into a grassland during spring 2008. The sown grassland mix consisted of $41 \%$ tall fescue, $19 \%$ lolium, $11 \%$ Kentucky bluegrass, $11 \%$ birdsfoot trefoil, $11 \%$ alsike clover, $7 \%$ white clover. Before the start of the first broiler batch (March 2009), the canopy was cut in order to offer a short canopy to the broilers. The field has a gentle slope down to the broiler house (Fig. 1).

\subsection{Organic broiler production system}

Five broiler batches were reared consecutively on the study site between March 2009 and November 2010. The GHG flux measurements presented in this paper were carried out during two batches only (batches 3 and 5). Batch 3 was studied from December 2009 to May 2010 (winter and early spring, denoted "WS" hereafter) while batch 5 was studied from August 2011 to December 2010 (late summer and autumn, or "SA").

The main characteristics of the two studied batches (number of animals, important dates, weight at slaughter) are listed in Table 1. During each batch, between 750 and 800 slow-growing strain broilers were reared in a broiler house of $75 \mathrm{~m}^{2}(l=12.5, L=6 \mathrm{~m})$ with straw bedding. After 35 days (batch WS) or 28 days (batch SA), two pop-holes of $2 \mathrm{~m}$ were continuously open and allowed the animals an unlimited access to the outdoor run of $2350 \mathrm{~m}^{2}$ surface area $(l=50, L=47 \mathrm{~m})$.

\subsection{Flux measurement technique}

Greenhouse gas fluxes were measured using static chambers (Smith et al., 1995; Conen and Smith, 1998). Square steel chambers $(L=50, l=50, H=30 \mathrm{~cm})$ were operated manually and fluxes were measured at (a maximum of) 16 locations on the run, and also at 3 locations just outside the fence to measure background fluxes (Fig. 1), using steel frames which were permanently inserted $10 \mathrm{~cm}$ into the soil. Among these frames, 9 were located within the first $15 \mathrm{~m}$ of the chicken house, as previous behavioural observations had shown that broilers are preferentially present in this zone (Zeltner and Hirt, 2003, 2008; Hegelund et al., 2005), and we therefore expected higher emissions due to a higher amount of nutrients (carbon, nitrogen) excreted.

Measurements were carried out routinely at regular time intervals after broilers gained first access to the run. In addition, measurements were also carried out after the last access 

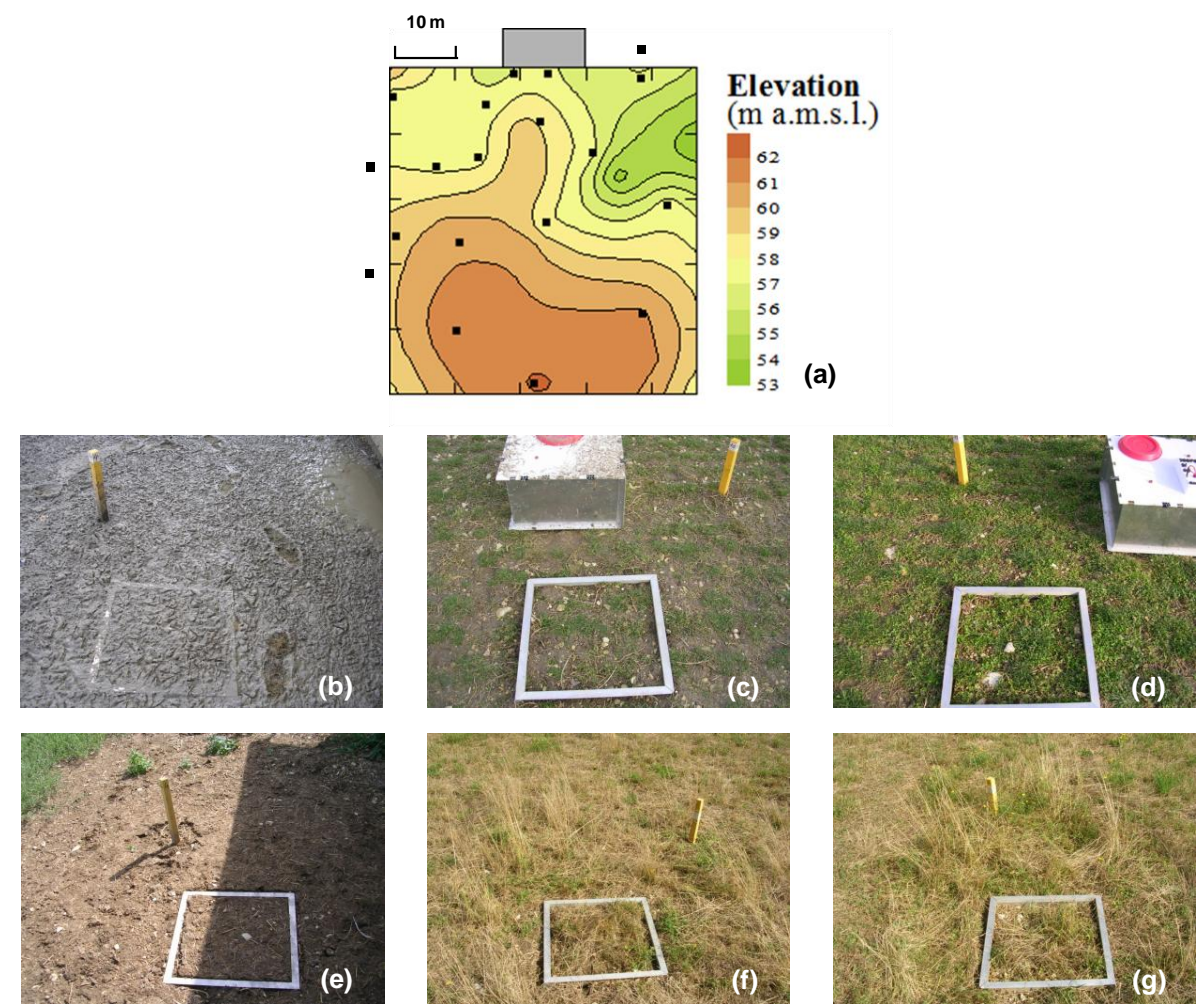

Fig. 1. (a) Site map showing the approximately square-shaped fenced-in outdoor run $(50 \times 47 \mathrm{~m})$, the broiler house (grey rectangle at the top), the topography of the outdoor run, and the distribution of the static chambers (black square). (b-g) Photographic records of the state of soil and vegetation, showing differences in soil moisture, vegetation density and soil compaction for chamber frames located at $5 \mathrm{~m}(\mathbf{b}$, e), $24 \mathrm{~m} \mathrm{(c,} \mathrm{f)} \mathrm{and} 41 \mathrm{~m} \mathrm{(d,} \mathrm{g)} \mathrm{from} \mathrm{the} \mathrm{broiler} \mathrm{house.} \mathrm{Pictures} \mathrm{were} \mathrm{taken} \mathrm{on} 2$ March 2010 (b-d) and on 27 July 2010 (e-g), a.m.s.l.= above mean sea level.

Table 1. Main characteristics of the two broiler batches during which GHG fluxes were measured.

\begin{tabular}{|c|c|c|c|c|c|c|}
\hline \multirow[t]{2}{*}{ Batch } & \multicolumn{2}{|c|}{ Number of animals } & \multirow{2}{*}{$\begin{array}{c}\text { Weight at slaughter } \\
\text { (kg/broiler) }\end{array}$} & \multicolumn{3}{|c|}{ Dates } \\
\hline & at start & at slaughter & & Chicks arrival & First outdoor access & Slaughter \\
\hline WS & 758 & 678 & 2.21 & 8 December 2009 & 13 January 2010 & 8 March 2010 \\
\hline SA & 788 & 711 & 2.23 & 3 August 2010 & 1 September 2010 & 10 November 2010 \\
\hline
\end{tabular}

(slaughter) to the run. On each day of flux measurements, chamber sampling was done in the early to mid-afternoon i.e. between 14:00 to 16:00. At the start of each flux measurement, the chambers were placed on top of the steel frames, their lid being equipped with a septum for gas sampling using a $50 \mathrm{ml}$ syringe. Four air samples of $15 \mathrm{ml}$ were taken at $t=0, t=10, t=20$ and $t=30 \mathrm{~min}$ and injected into 5$\mathrm{ml}$ evacuated vials closed with leak free septa before being analysed using gas chromatography (Agilent $6890 \mathrm{~N}$, Agilent Technologies, Santa Clara, USA). The trace gas $\left(\mathrm{CO}_{2}, \mathrm{~N}_{2} \mathrm{O}\right.$ and $\mathrm{CH}_{4}$ ) exchange flux between soil/vegetation/atmosphere is proportional to the temporal change in head-space gas con- centration $(\mathrm{C})$ :

$$
F(t)=\frac{V}{A} \frac{\partial \mathrm{C}}{\partial t}=H \frac{\partial \mathrm{C}}{\partial t}
$$

with $V$ the head-space volume, $A$ the surface area and $H$ the chamber height. In practice, the slope of the linear regression of gas concentration vs. time was used. It should be recognised that in theory the temporal evolution of concentration inside the closed chamber is curvilinear, owing to a gradual reduction over time of the soil/headspace concentration gradient and hence of the flux. However we did not fit non-linear functions because only four concentration points (one sample every 10 min during a half-hour) were available to constrain non-linear models, which, accounting for the uncertainty in individual concentration measurements, may lead to unstable 
solutions (e.g. Levy et al., 2011). The linear regression slope was deemed a more robust option, and the GHG flux data presented hereafter should be viewed as conservative estimates.

The lower detectable fluxes (LDF) for $\mathrm{CO}_{2}, \mathrm{~N}_{2} \mathrm{O}$ and $\mathrm{CH}_{4}$ were determined on the basis of the precision of GHG concentrations measured by GC. Values of LDF were calculated following Flechard et al. (2005) as $\mathrm{LDF}=H \cdot \Delta \mathrm{C}_{\text {noise }} / \Delta t_{\mathrm{chb}}$, where $\Delta \mathrm{C}_{\text {noise }}$ is the noise or lower detectable concentration difference, and $\Delta t_{\mathrm{chb}}$ is chamber closure duration (30 min). The noise levels for the three gases were defined as twice the standard deviation of successive concentration measurements of gas standards during calibrations, and determined in our $\mathrm{GC}$ system as $\Delta \mathrm{C}_{\text {noise }}\left(\mathrm{CO}_{2}\right)=11 \mathrm{ppm}$ at $600 \mathrm{ppm}$ (precision $\sim 2 \%$ ), $\Delta \mathrm{C}_{\text {noise }}\left(\mathrm{N}_{2} \mathrm{O}\right)=21 \mathrm{ppb}$ at $475 \mathrm{ppb}$ (precision $\sim 4 \%$ ), and $\Delta \mathrm{C}_{\text {noise }}\left(\mathrm{CH}_{4}\right)=0.06 \mathrm{ppm}$ at $2.05 \mathrm{ppm}$ (precision $\sim 3 \%$ ). The resulting $\mathrm{LDF}$ values (using $H=$ $0.3 \mathrm{~m}$ ) were $0.1 \mu \mathrm{mol} \mathrm{CO} \mathrm{m}^{-2} \mathrm{~s}^{-1}, 6.7 \mathrm{ng} \mathrm{N}_{2} \mathrm{O} \mathrm{m}^{-2} \mathrm{~s}^{-1}$ and $7.1 \mathrm{ng} \mathrm{CH}_{4} \mathrm{~m}^{-2} \mathrm{~s}^{-1}$.

\subsection{Soil and meteorological measurements}

The site was equipped with a meteorological station and datalogger (CR10X, Campbell Scientific Ltd., Loughborough, UK) providing half-hourly means of air temperature, global radiation, wind speed and rainfall. Soil temperature was measured at $-5 \mathrm{~cm}$, while volumetric soil water content (SWC) at $-5 \mathrm{~cm}$ was measured using time domain reflectometry (TDR) probes (CS616, Campbell Scientific Ltd., Loughborough, UK). These measurements were made on site but outside the run, at a distance of around $150 \mathrm{~m}$ from the broiler house. To fill occasional SWC data gaps mechanistically, a simple one-dimensional soil water budget model was used. The soil water balance of the uppermost $10 \mathrm{~cm}$ of topsoil was computed every half-hour using the following equation:

$$
\frac{\mathrm{d} \Phi}{\mathrm{d} t}=\frac{1}{Z_{\mathrm{s}}}(P-I-D-E)
$$

with $\Phi$ the mean soil water content $\left(\mathrm{m}^{3} \mathrm{~m}^{-3}\right)$ of the considered topsoil layer, $Z_{\mathrm{s}}=0.1$ the depth of considered topsoil layer (m), $P$ the precipitation rate $\left(\mathrm{m}^{3} \mathrm{~m}^{-2} 30 \mathrm{~min}^{-1}\right)$, $I$ the rate of rainfall interception by the canopy $\left(\mathrm{m}^{3} \mathrm{~m}^{-2}\right.$ $\left.30 \mathrm{~min}^{-1}\right), D$ the gravitational drainage rate from the top $10-\mathrm{cm}$ layer down to the deeper layers $\left(\mathrm{m}^{3} \mathrm{~m}^{-2} 30 \mathrm{~min}^{-1}\right)$, and $E$ the evapotranspiration flux $\left(\mathrm{m}^{3} \mathrm{~m}^{-2} 30 \mathrm{~min}^{-1}\right)$. $D$ was parameterised as a function of $\Phi$ based on rainless nighttime observations of the rate of SWC change (when also both $E=0$ and $P=0$ ). $I$ was modelled as a function of precipitation rate and leaf area index (LAI) according to Norman and Campbell (1983). E was modelled using the PenmanMonteith equation (Monteith, 1965), with stomatal resistance of the grass being adjusted on a monthly basis for the modelled SWC to fit the observations by TDR.

\subsection{Spatial integration of GHG fluxes}

For each measurement day (Table 2), the spatial integration of GHG fluxes was carried out using geostatistical methods with the SURFER software (Golden Software, Golden, USA). A grid map was generated with its origin at the top-left corner of the map. On each measurement day, the GHG flux values on the run were used to generate a map of fluxes with a $1 \times 1 \mathrm{~m}$ resolution; the mean of the control chambers was used as background flux around the fringes of the run. As datasets were small (about 20 observations per measurement day), kriging and radial basis function interpolation methods were selected. Gridded fluxes were summed to provide spatial integrals for each GHG and each measurement day. The average of both interpolation methods was used in the rest of the study.

\subsection{Temporal gap-filling and integration of GHG fluxes}

To fill gaps between two measurement days, and to compute time-integrated fluxes over a batch or a year, three methods were used and compared. First, the temporal mean of daily spatial integrals was calculated and multiplied by the duration of the batch. Second, a simple linear dot-to-dot interpolation was carried out between daily spatial integrals obtained from Sect. 2.5. Note that the first and second methods would be equivalent if consecutive measurement days were all equidistant, which was not the case here. Third, to provide more mechanistically-based estimates of GHG fluxes, relationships between measured fluxes and assumed control variables, such as soil temperature and SWC, were investigated. These functions are detailed in Sect. 3.3. To derive estimates of batch-scale fluxes, temporal integrals were calculated by summing actual measurement-based spatial flux integrals for each measurement day and gap-filled fluxes inbetween. The batch-scale integrals included data from first outdoor access of the $N$-th batch to the first outdoor access of the following $(N+1)$-th batch, since we considered that emissions before first outdoor access of batch $N+1$ should be attributed to batch $N$.

\subsection{Outdoor nitrogen excretion}

In order to estimate the amount of $\mathrm{N}$ excreted on the run during batches WS and SA, mass balances of N, P and K were computed at the house + run scale. These mass balances are presented in another study (Meda, 2011) in which more methodological details are given. Total ingestion was calculated as the product of feed consumption and nutrient content of the diet, ignoring in a first approach any ingestion of nonfeed material from the outdoor run. Body retention for N, P, and $\mathrm{K}$ was calculated according to CORPEN (2006). Total excretion was calculated by difference between total ingestion and body retention. Straw and litter were weighed, sampled and analysed for chemical composition in N, P and K, 
Table 2. Summary of $\mathrm{N}_{2} \mathrm{O}, \mathrm{CO}_{2}$ and $\mathrm{CH}_{4}$ chamber flux statistics for each measurement date.

\begin{tabular}{|c|c|c|c|c|c|c|c|c|c|c|c|c|c|c|c|c|c|c|c|c|}
\hline \multirow[b]{2}{*}{$\begin{array}{l}\mathrm{N}_{2} \mathrm{O} \text { fluxes } \\
\left(\mathrm{ng} \mathrm{m}^{-2} \mathrm{~s}^{-1}\right)\end{array}$} & & \multicolumn{8}{|c|}{ WS batch } & \multicolumn{2}{|c|}{ Intermediate } & \multicolumn{9}{|c|}{ SA batch } \\
\hline & & 11.12 .09 & 19.01 .10 & 28.01 .10 & 09.02 .10 & 19.02 .10 & 02.03 .10 & 09.03 .10 & 06.04 .10 & 04.05 .10 & 29.07 .10 & 27.08 .10 & 02.09 .10 & 16.09 .10 & 27.09 .10 & 07.10 .10 & 18.10 .10 & 04.11 .10 & 24.11 .10 & 13.12 .10 \\
\hline \multirow{5}{*}{$\begin{array}{l}\text { Outdoor run } \\
\text { (within fence) }\end{array}$} & $N$ & 16 & 8 & 6 & 5 & 15 & 14 & 10 & 12 & 13 & 16 & 16 & 8 & 8 & 8 & 16 & 16 & 16 & 16 & 16 \\
\hline & Mean & -4 & 9 & 20 & 31 & 25 & 19 & 56 & 166 & 1 & 12 & 63 & 12 & 42 & 841 & 49 & 70 & 48 & 15 & 123 \\
\hline & Median & -5 & 5 & 14 & 39 & 13 & 13 & 11 & 15 & 0 & 3 & 16 & 7 & 14 & 94 & 30 & 10 & 45 & 12 & 6 \\
\hline & Min & -32 & 1 & 6 & 5 & -6 & 6 & -18 & 2 & -5 & -4 & 4 & 1 & -3 & 16 & 0 & -12 & 14 & 0 & -11 \\
\hline & Max & 21 & 28 & 45 & 60 & 80 & 63 & 323 & 1026 & 8 & 162 & 476 & 39 & 219 & 5910 & 159 & 597 & 96 & 53 & 1871 \\
\hline \multirow{5}{*}{$\begin{array}{l}\text { Control } \\
\text { (outside fence) }\end{array}$} & $N$ & 3 & 1 & 1 & 2 & 2 & 2 & 0 & 2 & 3 & 3 & 3 & 2 & 2 & 2 & 3 & 2 & 3 & 2 & 2 \\
\hline & Mean & 10 & 10 & 15 & 0 & 10 & 11 & & 2 & 3 & 3 & 13 & 6 & 5 & 5 & 5 & 4 & 11 & 4 & -1 \\
\hline & Median & 15 & 10 & 15 & 0 & 10 & 11 & & 2 & 2 & 2 & 15 & 6 & 5 & 5 & 9 & 4 & 1 & 4 & -1 \\
\hline & Min & -10 & 10 & 15 & -16 & 4 & 10 & & -2 & 1 & 1 & 5 & 3 & -2 & 4 & -4 & 0 & -3 & 1 & -7 \\
\hline & Max & 26 & 10 & 15 & 15 & 16 & 11 & & 6 & 5 & 4 & 20 & 9 & 12 & 6 & 9 & 8 & 34 & 8 & 5 \\
\hline \multicolumn{2}{|l|}{$\begin{array}{l}R_{\text {eco }} \mathrm{CO}_{2} \text { fluxes } \\
\left(\mu \mathrm{mol} \mathrm{m}-\mathrm{m}^{-2} \mathrm{~s}^{-1}\right)\end{array}$} & 11.12 .09 & 19.01 .10 & 28.01 .10 & 09.02 .10 & 19.02 .10 & 02.03 .10 & 09.03 .10 & 06.04 .10 & 04.05 .10 & 29.07 .10 & 27.08 .10 & 02.09 .10 & 16.09 .10 & 27.09 .10 & 07.10 .10 & 18.10 .10 & 04.11 .10 & 24.11 .10 & 13.12 .10 \\
\hline \multirow{5}{*}{$\begin{array}{l}\text { Outdoor run } \\
\text { (within fence) }\end{array}$} & $N$ & 16 & 7 & 7 & 5 & 14 & 16 & 6 & 16 & 14 & 16 & 16 & 8 & 8 & 8 & 16 & 15 & 16 & 16 & 16 \\
\hline & Mean & 0.9 & 1.3 & 1.6 & 1.8 & 1.3 & 2.3 & 1.3 & 2.8 & 1.0 & 1.3 & 3.0 & 1.5 & 1.6 & 6.3 & 3.2 & 1.1 & 4.0 & 1.5 & 0.9 \\
\hline & Median & 0.9 & 1.1 & 1.6 & 1.6 & 1.0 & 2.1 & 0.7 & 2.5 & 1.0 & 1.1 & 2.7 & 1.5 & 1.5 & 3.7 & 2.8 & 0.8 & 3.6 & 1.4 & 0.8 \\
\hline & Min & 0.2 & 0.7 & 0.6 & 1.0 & 0.3 & 0.9 & 0.2 & 0.9 & 0.2 & 0.3 & 1.7 & 0.5 & 0.7 & 2.8 & 1.2 & 0.4 & 1.5 & 1.0 & 0.2 \\
\hline & Max & 1.9 & 2.5 & 2.5 & 2.7 & 3.9 & 5.0 & 3.1 & 5.3 & 2.1 & 2.5 & 5.7 & 2.6 & 3.1 & 24.2 & 5.8 & 3.4 & 10.6 & 2.2 & 3.7 \\
\hline \multirow{5}{*}{$\begin{array}{l}\text { Control } \\
\text { (outside fence) }\end{array}$} & $N$ & 3 & 1 & 1 & 1 & 3 & 3 & 1 & 3 & 2 & 3 & 3 & 2 & 2 & 2 & 3 & 2 & 3 & 2 & 2 \\
\hline & Mean & 0.9 & 0.7 & 0.9 & 0.4 & 0.7 & 1.5 & 0.9 & 4.0 & 1.3 & 1.3 & 2.8 & 1.2 & 1.2 & 2.0 & 2.4 & 1.2 & 2.2 & 1.0 & 0.6 \\
\hline & Median & 1.1 & 0.7 & 0.9 & 0.4 & 0.7 & 1.2 & 0.9 & 3.0 & 1.3 & 1.4 & 2.3 & 1.2 & 1.2 & 2.0 & 2.6 & 1.2 & 2.0 & 1.0 & 0.6 \\
\hline & Min & 0.2 & 0.7 & 0.9 & 0.4 & 0.5 & 0.9 & 0.9 & 2.6 & 1.1 & 0.9 & 2.1 & 0.5 & 1.0 & 1.8 & 1.3 & 0.5 & 0.3 & 1.0 & 0.1 \\
\hline & Max & 1.4 & 0.7 & 0.9 & 0.4 & 0.9 & 2.5 & 0.9 & 6.5 & 1.4 & 1.7 & 4.0 & 1.9 & 1.5 & 2.1 & 3.4 & 2.0 & 4.2 & 1.0 & 1.1 \\
\hline \multicolumn{2}{|l|}{$\begin{array}{l}\mathrm{CH}_{4} \text { fluxes } \\
\left(\mathrm{ng} \mathrm{m}^{-2} \mathrm{~s}^{-1}\right)\end{array}$} & 11.12 .09 & 19.01 .10 & 28.01 .10 & 09.02 .10 & 19.02 .10 & 02.03 .10 & 09.03 .10 & 06.04 .10 & 04.05 .10 & 29.07 .10 & 27.08 .10 & 02.09 .10 & 16.09 .10 & 27.09 .10 & 07.10 .10 & 18.10 .10 & 04.11 .10 & 24.11 .10 & 13.12 .10 \\
\hline \multirow{5}{*}{$\begin{array}{l}\text { Outdoor run } \\
\text { (within fence) }\end{array}$} & $N$ & 16 & 7 & 7 & 5 & 10 & 8 & 9 & 6 & 16 & 16 & 16 & 8 & 8 & 8 & 16 & 15 & 16 & 16 & 13 \\
\hline & Mean & -10 & -8 & 3 & -3 & 1 & 114 & -1 & -6 & -2 & -6 & -4 & -4 & -3 & 13 & 12 & 0 & 48 & 5 & -6 \\
\hline & Median & -6 & -8 & 0 & -2 & -5 & 17 & 9 & -17 & -1 & -8 & -4 & -3 & -4 & 2 & -3 & -2 & 19 & 1 & -3 \\
\hline & Min & -47 & -18 & -50 & -23 & -39 & -13 & -27 & -30 & -22 & -27 & -11 & -9 & -17 & -6 & -42 & -18 & -2 & -5 & -29 \\
\hline & Max & 17 & 6 & 41 & 28 & 44 & 566 & 22 & 56 & 14 & 17 & 9 & -1 & 15 & 86 & 115 & 27 & 169 & 35 & 9 \\
\hline \multirow{5}{*}{$\begin{array}{l}\text { Control } \\
\text { (outside fence) }\end{array}$} & $N$ & 3 & 2 & 2 & 2 & 1 & 3 & 0 & 1 & 2 & 3 & 3 & 2 & 2 & 2 & 3 & 2 & 3 & 2 & 2 \\
\hline & Mean & -3 & -7 & 4 & -12 & -15 & 2 & & -9 & -2 & 0 & -2 & -8 & -6 & -4 & -9 & -1 & -2 & -9 & -6 \\
\hline & Median & 2 & -7 & 4 & -12 & -15 & -5 & & -9 & -2 & 0 & -2 & -8 & -6 & -4 & -21 & -1 & -1 & -9 & -6 \\
\hline & Min & -12 & -9 & -8 & -21 & -15 & -29 & & -9 & -4 & -3 & -8 & -8 & -7 & -11 & -44 & -4 & -5 & -10 & -11 \\
\hline & Max & 3 & -5 & 16 & -2 & -15 & 40 & & -9 & 0 & 4 & 3 & -7 & -6 & 3 & 36 & 1 & 1 & -7 & 0 \\
\hline
\end{tabular}

respectively at the beginning of the batch, and at the end of the batch. For non-volatile compounds (P and K), outdoor excretion was computed according to Eq. (3). The average outdoor/total excretion ratio was then calculated for $\mathrm{P}$ and $\mathrm{K}$, and then applied to $\mathrm{N}$ to estimate the outdoor $\mathrm{N}$ excretion.

$X_{\text {Outdoor }_{\text {excretion }}}=X_{\text {Total }_{\text {excretion }}}-\left(X_{\text {Litter }}-X_{\text {Straw }}\right)$

where $X$ is the mass of either $\mathrm{P}$ or $\mathrm{K}$.

\subsection{Temporal and spatial variations in soil nutrient $(P, N, C)$ stocks}

Changes in soil organic carbon (SOC), total nitrogen $(\mathrm{N})$ and total phosphorus $(\mathrm{P})$ stocks in the soil of the run were estimated in order to assess the temporal and spatial impacts of broiler foraging on soil biogeochemistry. Soil samples were taken before the first broilers had access to the run (March 2009) and after the end of the last batch (December 2010). The run was divided into 25 grid squares of equal surface area. In each grid square, 5 to 6 auger samples were dug up to characterize the $0-15 \mathrm{~cm}$ horizon. Bulk density $\left(\mathrm{g} \mathrm{cm}^{-3}\right.$ soil) was measured by the cylinder method for each sample and a correction for the stone content estimated by $2 \mathrm{~mm}$ mesh sieving was applied. These samples were then mixed to create a composite sample for each grid square for chemical analysis. Total contents in $\mathrm{C}$ and $\mathrm{N}\left(\mathrm{g} \mathrm{kg}^{-1}\right.$ soil) were measured by dry combustion (ISO, 1995, 1998) while P content was measured with spectrometry (ISO, 1994). For each grid square, stocks were finally calculated according to Eq. (4).

$S_{X}=A \cdot d \cdot \theta_{X} \cdot h$ with $X$ the considered nutrient (C, N or P); $S_{X}$ the stock of $X$ in the soil $(\mathrm{kg}) ; A$ the area of the grid square $\left(\mathrm{m}^{2}\right) ; d$ the bulk density ( $\mathrm{kg} \mathrm{m}^{-3}$ soil); $\theta_{X}$ the content in $X$ of the soil (in $\mathrm{kg} \mathrm{kg}^{-1}$ soil) and $h$ the horizon thickness (m).

Stock variations for each grid square of the run were then calculated as the difference between initial and final stocks. Data were interpolated spatially by kriging in order to provide a spatially integrated stock variation for the whole run.

\subsection{Outdoor spatial distribution of broilers}

The spatial distribution of broilers on the run was obtained by a series of behavioural observations, which were performed on days 35, 49 and 63 of each rearing period (5 and 7 scans per day for batches WS and SA, respectively), using the method described by Germain et al. (2010, 2011). About 100 broilers were tagged with a numbered poncho placed through the back of the neck. During each observation period, the locations of the tagged broilers on the run were recorded according to 16 predefined zones. To that purpose, 4 equal stripes of $11.75 \mathrm{~m}$ wide and perpendicular to the broiler house were divided into 4 zones of respectively 5 , 10,15 and $20 \mathrm{~m}$ wide parallel to the broiler house. Data were interpolated spatially by kriging in order to derive a spatially explicit "foraging index", which represents a percentage of total outdoor time spent in each square meter of the run. 


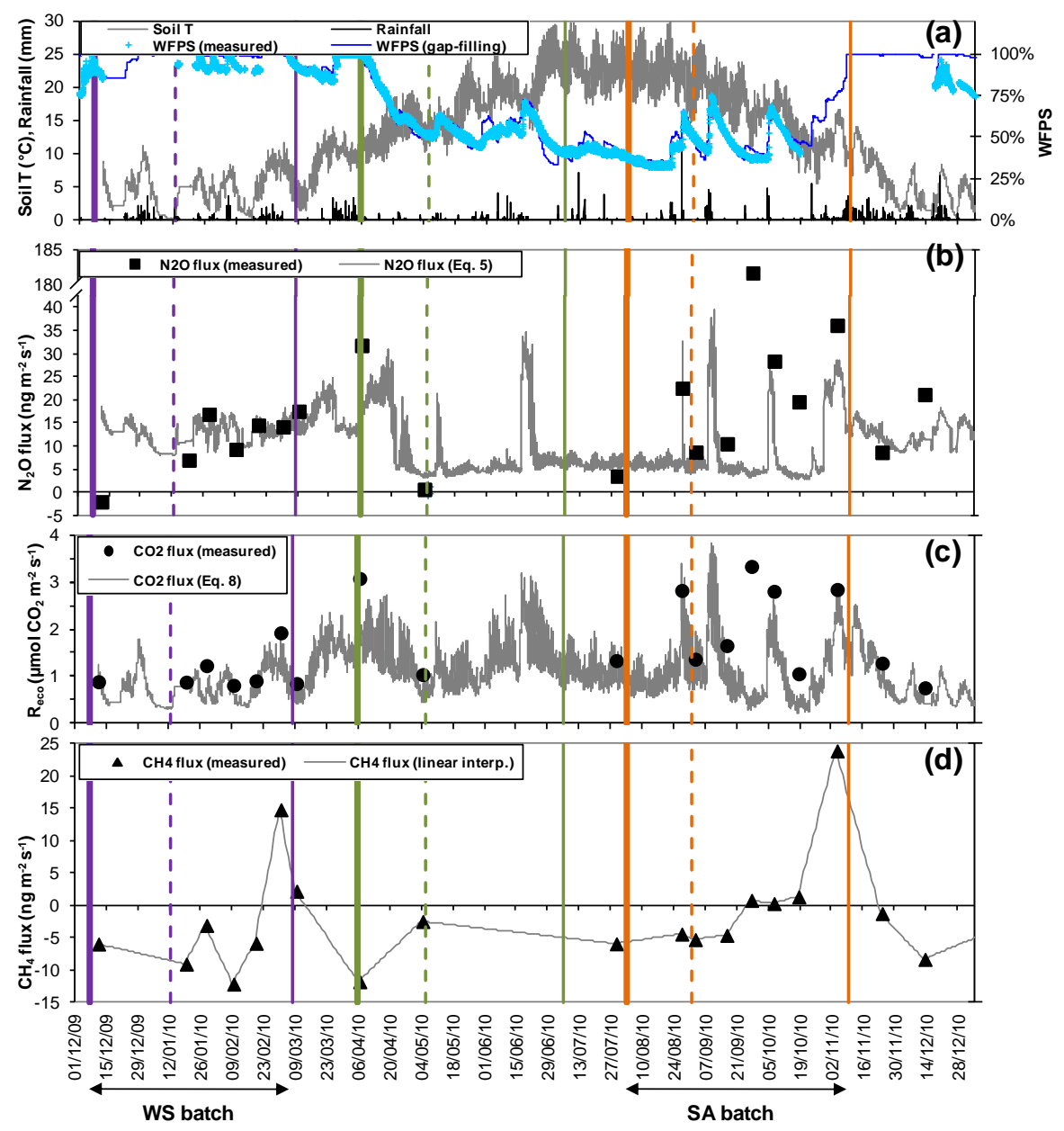

Fig. 2. Overview of soil conditions, meteorology, measured (black symbols) and gap-filled (grey lines) GHG fluxes at the outdoor run scale. (a) Soil temperature at $-5 \mathrm{~cm}$ depth (Soil $T$ ), rainfall and water-filled pore space (WFPS). (b) $\mathrm{N}_{2} \mathrm{O}$ fluxes. (c) Ecosystem respiration ( $R_{\text {eco }}$ ). (d) $\mathrm{CH}_{4}$ fluxes. GHG fluxes for each measurement day are spatial integrals computed from individual measurements using geostatistical methods. Vertical lines indicate batch start (thick, continuous), broilers first outdoor access (dotted) and slaughter (thin, continuous).

\section{Results}

\subsection{Overview of measured chamber fluxes}

Measured $\mathrm{N}_{2} \mathrm{O}$ and $\mathrm{CH}_{4}$ fluxes were extremely variable in time and space for both batches, with temporal variations shown in Table 2 and Fig. 2 and spatial variability shown in Figs. 3, 4 and 5 for the three GHG. $\mathrm{N}_{2} \mathrm{O}$ fluxes ranged -32 from to $+1026 \mathrm{ng} \mathrm{N}_{2} \mathrm{O} \mathrm{m}^{-2} \mathrm{~s}^{-1}$ and from -12 to $+5910 \mathrm{ng} \mathrm{N}_{2} \mathrm{O} \mathrm{m}^{-2} \mathrm{~s}^{-1}$ during batches WS and SA, respectively, with the usual atmospheric science sign convention of plus for emissions and minus for deposition. The emission peaks observed during the study mostly occurred in chambers located closest to the house and the two popholes for outdoor access (Fig. 3). Uptake fluxes on the run represented about $21 \%$ and $14 \%$ of all individual chamber measurements during batches WS and SA, respectively.
$\mathrm{CH}_{4}$ exchange was largely dominated by small uptake fluxes, observed in $64 \%$ and $61 \%$ of all individual flux data for batches WS and SA, respectively. Nevertheless, fluxes ranged from -50 to $+566 \mathrm{ng} \mathrm{CH}_{4} \mathrm{~m}^{-2} \mathrm{~s}^{-1}$ and from -42 to $+169 \mathrm{ng} \mathrm{CH}_{4} \mathrm{~m}^{-2} \mathrm{~s}^{-1}$ during batches WS and SA, respectively, suggesting that the net sink activity on the run was offset by rare emission peaks (Table 2). Once again, these peaks were observed in the chambers located closest to the broiler house (Fig. 4).

Concerning $\mathrm{CO}_{2}$, emission fluxes generated by the (heterotrophic and autotrophic) respiration of the soil + grass ecosystem $\left(R_{\text {eco }}\right)$ ranged from +0.2 to $+5 \mu \mathrm{mol} \mathrm{CO}_{2} \mathrm{~m}^{-2} \mathrm{~s}^{-1}$ and from +0.2 to $+24 \mu \mathrm{mol} \mathrm{CO} \mathrm{Cm}^{-2} \mathrm{~s}^{-1}$ for batches WS and $\mathrm{SA}$, respectively. 


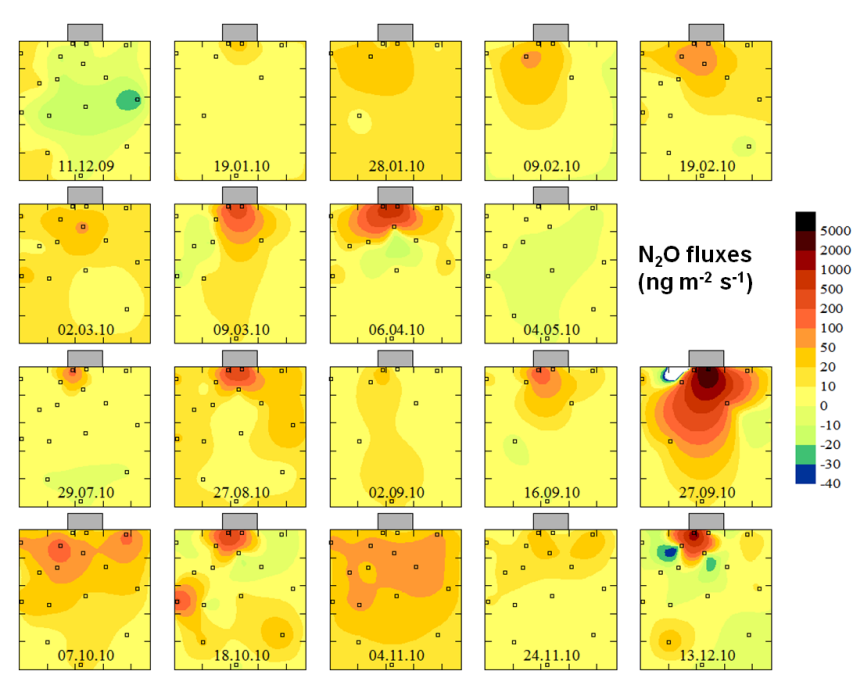

Fig. 3. Spatially interpolated (kriging method) maps of $\mathrm{N}_{2} \mathrm{O}$ fluxes. For each measurement day, the kriging was done on the basis of the available chamber measurements as shown by the number of chambers displayed in each map.

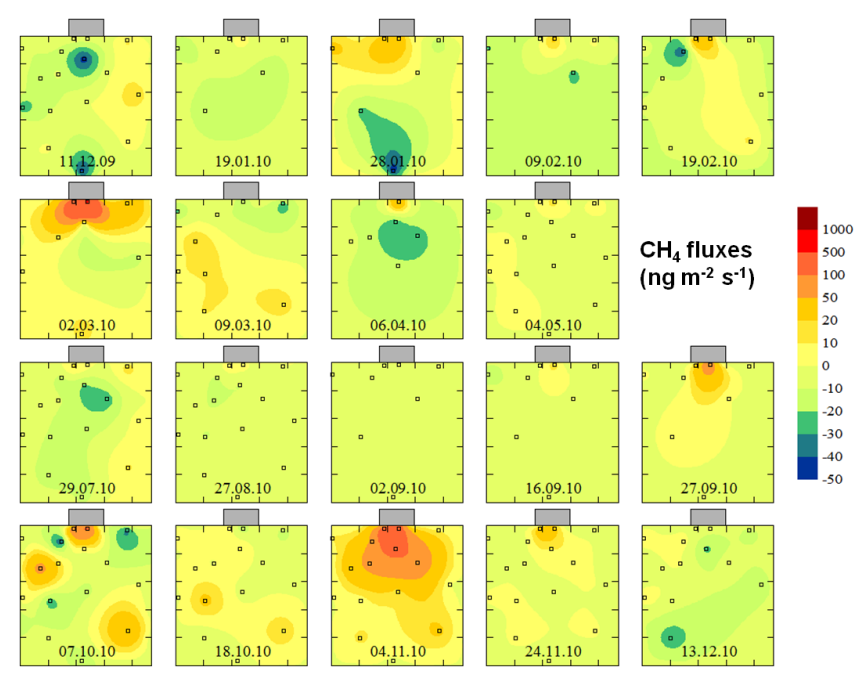

Fig. 4. Spatially interpolated (kriging method) maps of $\mathrm{CH}_{4}$ fluxes. Comments as in Fig. 3.

\subsection{Spatially integrated GHG fluxes}

Figures 3, 4 and 5 present the spatial distributions of $\mathrm{N}_{2} \mathrm{O}$, $\mathrm{CH}_{4}$ and $\mathrm{CO}_{2}$ fluxes, respectively, for each measurement day and based on kriging. Table 3 summarizes the spatial $\mathrm{N}_{2} \mathrm{O}$, $\mathrm{CH}_{4}$ and $\mathrm{CO}_{2}$ flux integrals estimated by kriging and radial basis function. The discrepancy between the two interpolation methods was generally below $10 \%$ and on average $-4 \%,-0.9 \%$ and $-1.3 \%$ for $\mathrm{N}_{2} \mathrm{O}, \mathrm{CH}_{4}$ and $\mathrm{CO}_{2}$ fluxes, respectively, showing that the spatial integrals are not very sensitive to the interpolation method.

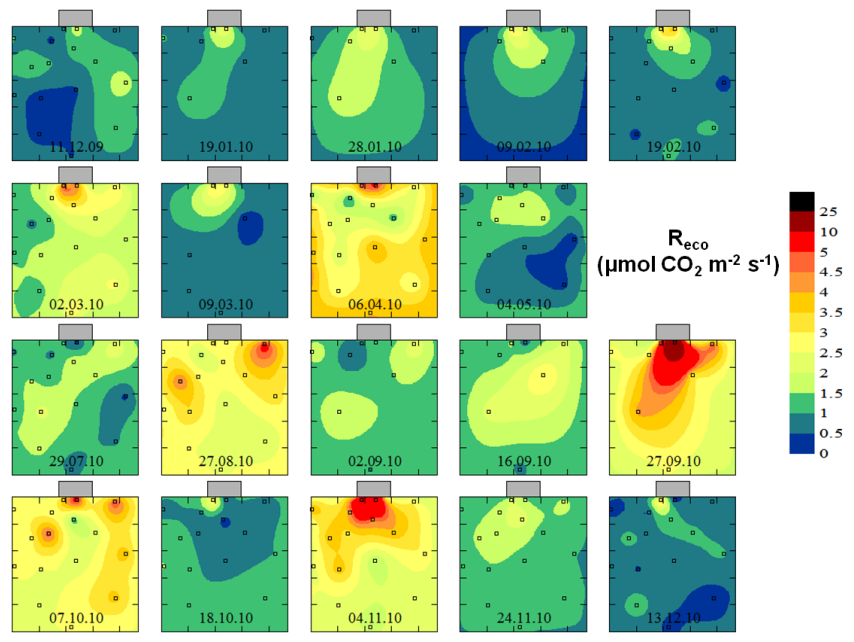

Fig. 5. Spatially interpolated (kriging method) maps of ecosystem respiration $R_{\text {eco }}$ (not including broiler respiration). Comments as in Fig. 3.

Plot-scale $\mathrm{N}_{2} \mathrm{O}$ fluxes ranged from -2.1 to $+31.8 \mathrm{ng} \mathrm{N}_{2} \mathrm{O}$ $\mathrm{m}^{-2} \mathrm{~s}^{-1}$ and from +3.5 to $+181.7 \mathrm{ng} \mathrm{N}_{2} \mathrm{O} \mathrm{m}^{-2} \mathrm{~s}^{-1}$, respectively for all measurement days of batches WS and SA. Plotscale $\mathrm{CH}_{4}$ fluxes were frequently negative, confirming a sink activity at the scale of the run, with values for different measurement days ranging from -12.2 to +15.1 and from -8.3 to $+23.7 \mathrm{ng} \mathrm{CH}_{4} \mathrm{~m}^{-2} \mathrm{~s}^{-1}$, respectively, for batches WS and SA. The range of plot-scale integrals of respiration of the ecosystem $R_{\mathrm{eco}}$, from +0.8 to $+3.1 \mu \mathrm{mol} \mathrm{CO}_{2} \mathrm{~m}^{-2} \mathrm{~s}^{-1}$ and from +0.7 to $+3.3 \mu \mathrm{mol} \mathrm{CO}_{2} \mathrm{~m}^{-2} \mathrm{~s}^{-1}$ respectively for batches WS and SA (Table 3), indicates somewhat weaker spatial patterns of $R_{\text {eco }}$ than of $\mathrm{N}_{2} \mathrm{O}$, even if large $\mathrm{CO}_{2}$ fluxes were also clearly associated with the area just outside the broiler house (Fig. 5).

\subsection{Temporal gap-filling functions}

To derive annual-scale estimates of $\mathrm{N}_{2} \mathrm{O}$ fluxes based on a discrete time series of measurements, one possible method consists in an investigation of the relationships of $\mathrm{N}_{2} \mathrm{O}$ emission fluxes to environmental variables known to control $\mathrm{N}_{2} \mathrm{O}$ production and consumption in soils, with meteorology and soil moisture key controlling variables (Davidson, 1991; Granli and Bøckman, 1994). While the effect of soil temperature on $\mathrm{N}_{2} \mathrm{O}$ emissions is predictably positive, the effect of water-filled pore space (WFPS, expressed as the percentage ratio of actual SWC to saturation SWC), is unlikely to be monotonous from 0 to $100 \%$ WFPS, since in wet saturated soils total denitrification is expected to proceed all the way to $\mathrm{N}_{2}$, with less or no potential for $\mathrm{N}_{2} \mathrm{O}$ to evolve. At lower WFPS, nitrification is expected to be the dominant mechanism for $\mathrm{N}_{2} \mathrm{O}$ emission (Davidson, 1991). As a result, the overall effect of WFPS on the $\mathrm{N}_{2} \mathrm{O}$ emission potential can be thought of as bell-shaped, with maximum likelihood of 
Table 3. Summary of spatially integrated GHG fluxes for each measurement day, computed using (an average of) kriging and radial basis functions to interpolate between all available individual chamber measurements. Soil temperature and water-filled pore space (WFPS) are values observed at the same time as GHG fluxes, i.e. generally around mid-afternoon.

\begin{tabular}{|c|c|c|c|c|c|c|c|c|c|c|c|c|c|c|}
\hline & \multirow[b]{2}{*}{$\begin{array}{r}\text { Soil } T \\
5 \mathrm{~cm}\left({ }^{\circ} \mathrm{C}\right)\end{array}$} & \multirow[b]{2}{*}{$\begin{array}{c}\text { WFPS } \\
5 \mathrm{~cm}(\%)\end{array}$} & \multicolumn{4}{|c|}{$\mathrm{N}_{2} \mathrm{O}$ flux $\left(\mathrm{ng} \mathrm{N}_{2} \mathrm{O} \mathrm{m}^{-2} \mathrm{~s}^{-1}\right)$} & \multicolumn{4}{|c|}{$\mathrm{CH}_{4}$ flux (ng $\left.\mathrm{CH}_{4} \mathrm{~m}^{-2} \mathrm{~s}^{-1}\right)$} & \multicolumn{4}{|c|}{$R_{\mathrm{eco}} \mathrm{CO}_{2}\left(\mu \mathrm{molm} \mathrm{m}^{-2} \mathrm{~s}^{-1}\right)$} \\
\hline & & & Kriging & $\begin{array}{l}\text { Radial } \\
\text { basis } \\
\text { function }\end{array}$ & $\%$ diff.* & Average & Kriging & $\begin{array}{l}\text { Radial } \\
\text { basis } \\
\text { function }\end{array}$ & $\%$ diff. $*$ & Average & Kriging & $\begin{array}{l}\text { Radial } \\
\text { basis } \\
\text { function }\end{array}$ & $\%$ diff.* & Average \\
\hline \multicolumn{15}{|l|}{ WS batch } \\
\hline 11 Dec 2009 & 8.6 & $87 \%$ & -2.2 & -1.9 & $-13.5 \%$ & -2.1 & -5.9 & -6.0 & $0.3 \%$ & -5.9 & 0.9 & 0.9 & $0.0 \%$ & 0.9 \\
\hline 19 Jan 2010 & 5.1 & $100 \%$ & 6.9 & 7.0 & $0.7 \%$ & 7.0 & -9.1 & -9.0 & $-0.3 \%$ & -9.1 & 0.9 & 0.9 & $-1.2 \%$ & 0.9 \\
\hline 28 Jan 2010 & 4.6 & $94 \%$ & 16.8 & 16.9 & $0.4 \%$ & 16.9 & -3.0 & -3.1 & $2.0 \%$ & -3.1 & 1.2 & 1.2 & $-1.1 \%$ & 1.2 \\
\hline 9 Feb 2010 & 4.8 & $93 \%$ & 9.6 & 9.0 & $-6.9 \%$ & 9.3 & -12.1 & -12.2 & $1.4 \%$ & -12.1 & 0.8 & 0.8 & $-3.9 \%$ & 0.8 \\
\hline 19 Feb 2010 & 5.6 & $91 \%$ & 14.5 & 14.5 & $-0.1 \%$ & 14.5 & -5.3 & -6.4 & $19.5 \%$ & -5.8 & 0.9 & 0.9 & $-0.7 \%$ & 0.9 \\
\hline 2 Mar 2010 & 11.4 & $99 \%$ & 14.2 & 14.2 & $0.0 \%$ & 14.2 & 14.5 & 15.1 & $3.9 \%$ & 14.8 & 1.9 & 1.9 & $-1.1 \%$ & 1.9 \\
\hline 9 Mar 2010 & 4.6 & $91 \%$ & 18.2 & 16.9 & $-7.4 \%$ & 17.5 & 2.0 & 2.5 & $23.1 \%$ & 2.2 & 0.9 & 0.8 & $-4.1 \%$ & 0.8 \\
\hline 6 Apr 2010 & 13.9 & $100 \%$ & 33.2 & 30.3 & $-8.8 \%$ & 31.8 & -11.8 & -11.7 & $-0.7 \%$ & -11.8 & 3.1 & 3.1 & $0.8 \%$ & 3.1 \\
\hline \multicolumn{15}{|c|}{ Intermediate measurements } \\
\hline 4 May 2010 & 14.5 & $53 \%$ & 0.6 & 0.7 & $13.1 \%$ & 0.6 & -2.5 & -2.5 & $0.8 \%$ & -2.5 & 1.0 & 1.0 & $1.3 \%$ & 1.0 \\
\hline 29 Jul 2010 & 25.3 & $41 \%$ & 3.6 & 3.4 & $-5.5 \%$ & 3.5 & -5.9 & -5.9 & $0.8 \%$ & -5.9 & 1.3 & 1.3 & $-0.1 \%$ & 1.3 \\
\hline \multicolumn{15}{|l|}{ SA batch } \\
\hline 27 Aug 2010 & 23.6 & $64 \%$ & 22.8 & 22.2 & $-2.4 \%$ & 22.5 & -4.4 & -4.4 & $-0.6 \%$ & -4.4 & 2.8 & 2.8 & $-0.5 \%$ & 2.8 \\
\hline 2 Sep 2010 & 25.7 & $50 \%$ & 8.8 & 8.5 & $-3.5 \%$ & 8.7 & -5.2 & -5.3 & $3.1 \%$ & -5.3 & 1.4 & 1.4 & $-0.8 \%$ & 1.4 \\
\hline 16 Sep 2010 & 20.5 & $50 \%$ & 11.1 & 9.9 & $-10.2 \%$ & 10.5 & -4.6 & -4.6 & $1.9 \%$ & -4.6 & 1.7 & 1.6 & $-0.8 \%$ & 1.7 \\
\hline 27 Sep 2010 & 16.5 & $38 \%$ & 186.9 & 176.6 & $-5.5 \%$ & 181.7 & 0.9 & 0.7 & $-28.0 \%$ & 0.8 & 3.4 & 3.3 & $-2.5 \%$ & 3.3 \\
\hline 7 Oct 2010 & 20.7 & $64 \%$ & 28.9 & 27.8 & $-3.9 \%$ & 28.4 & 0.3 & 0.3 & $-19.2 \%$ & 0.3 & 2.8 & 2.8 & $-0.9 \%$ & 2.8 \\
\hline 18 Oct 2010 & 13.6 & $42 \%$ & 19.9 & 19.2 & $-3.7 \%$ & 19.6 & 1.3 & 1.3 & $0.6 \%$ & 1.3 & 1.1 & 1.1 & $0.2 \%$ & 1.1 \\
\hline 4 Nov 2010 & 16.6 & $77 \%$ & 36.5 & 35.8 & $-1.9 \%$ & 36.1 & 24.1 & 23.7 & $-1.9 \%$ & 23.9 & 2.9 & 2.8 & $-0.8 \%$ & 2.8 \\
\hline 24 Nov 2010 & 7.9 & $99 \%$ & 8.8 & 8.5 & $-3.5 \%$ & 8.6 & -1.1 & -1.4 & $20.0 \%$ & -1.2 & 1.3 & 1.3 & $-0.7 \%$ & 1.3 \\
\hline 13 Dec 2010 & 2.1 & $98 \%$ & 22.6 & 19.7 & $-12.7 \%$ & 21.1 & -8.4 & -8.3 & $-1.5 \%$ & -8.3 & 0.8 & 0.8 & $-0.8 \%$ & 0.8 \\
\hline
\end{tabular}

* Between kriging and radial basis function.

emission somewhere in the range 60-90\% WFPS, and minimum flux in either very dry or waterlogged conditions. The optimum range depends on the soil texture, $\mathrm{pH}$, substrate $\mathrm{C} / \mathrm{N}$ ratio and the composition of microbial communities.

To interpret the temporal variations in measured $\mathrm{N}_{2} \mathrm{O}$ fluxes, and to derive a mechanistically grounded gap-filling algorithm, we therefore adapted the empirical model used by Flechard et al. (2007a), in which a bell membership function (BMF, ranging from 0 to 1 ), characterizing the optimum WFPS range for $\mathrm{N}_{2} \mathrm{O}$ emission, was parameterized on the basis of plot-scale $\mathrm{N}_{2} \mathrm{O}$ fluxes (Table 3 ). The model responds exponentially to soil temperature, and the WFPS and temperature effects are multiplicative. Datasets for soil temperature and WFPS are also given in Table 3 . The $\mathrm{N}_{2} \mathrm{O}$ flux was modelled as:

$F_{\mathrm{N}_{2} \mathrm{O}}=e^{\left(c_{0}+c_{1} T_{\mathrm{s}}+c_{2} B(\mathrm{WFPS})\right)}$

with $F_{\mathrm{N}_{2} \mathrm{O}}$ expressed in $\mathrm{ng} \mathrm{N}_{2} \mathrm{O} \mathrm{m}^{-2} \mathrm{~s}^{-1}, T_{\mathrm{s}}$ the soil temperature at $-5 \mathrm{~cm}\left({ }^{\circ} \mathrm{C}\right)$, WFPS at $-5 \mathrm{~cm}$ expressed as a percentage of pore saturation (0-100), and $c_{0}, c_{1}$ and $c_{2}$ the parameters of a multiple linear regression between $\ln \left(F_{\mathrm{N}_{2} \mathrm{O}}\right)$ and the independent variables $T_{\mathrm{s}}$ and $B$ (WFPS). The bell membership function was given as:

$B(\mathrm{WFPS})=\frac{1}{1+\left(\frac{\mathrm{WFPS}-c}{a}\right)^{(2 b)}}$
The three parameters of the bell function ( $a$, width; $b$, taper coefficient; $c$, centre) were adjusted to maximize the goodness of fit between the observed data and the fluxes predicted by Eq. (5). With the parameters $a=20.1$ (\% WFPS), $b=6$ and $c=82.1$ (\% WFPS), the resulting regression parameters were $c_{0}=0.57 \pm 0.77, c_{1}=0.05 \pm 0.03$ and $c_{2}=1.87 \pm 0.61$, and the multiple $R^{2}$ was 0.41 . The observation-based model thus predicts a maximum likelihood of $\mathrm{N}_{2} \mathrm{O}$ emission at $82 \%$ WFPS, suggesting that denitrification was the dominant mechanism of $\mathrm{N}_{2} \mathrm{O}$ production at this site.

Note that two measurement days excluded from the data set used to derive these equations. First, 11 December 2009 (before batch WS) was removed because $\mathrm{N}_{2} \mathrm{O}$ uptake fluxes were considered to be representative of background conditions. Second, 27 September 2010 was removed because the low apparent value of WFPS $(38 \%)$ measured at $-5 \mathrm{~cm}$ depth could not be considered representative of soil moisture at the surface (1-2 cm depth), which was certainly influenced by rainfall of 24 September after a long dry period and triggered the highest measured $\mathrm{N}_{2} \mathrm{O}$ flux (Table 3 ).

Results of temporal $\mathrm{N}_{2} \mathrm{O}$ gap-filling using Eq. (5) are presented in Fig. 2b. Measured fluxes indicate a steady increase over the course of batch WS (cool, wet), which is reasonably well simulated by Eq. (5). By contrast, measured emissions during batch SA (warm and dry with wet episodes) were much more heterogeneous, being much more dependent on 
recent rainfall. Here, the gap-filling algorithm does reproduce some of the small-scale temporal variability, but the peak on 27 September is not simulated since the model is driven by SWC at $-5 \mathrm{~cm}$ depth, which did not respond much to the rainfall of 24 September. Thus, for the special case of this peak, we used a linear interpolation between 24 September up to 27 September, and again from 27 September down to the next measurement day on 7 October.

For the temporal gap-filling of the (spatially integrated) $R_{\text {eco }}\left(\mathrm{CO}_{2}\right)$ fluxes, an empirical algorithm based on functional relationships to $T_{\mathrm{S}}$ and WFPS was also derived. The temperature response of $R_{\text {eco }}$ for non water-limiting conditions (set arbitrarily by WFPS $>75 \%$ ) was determined by fitting the parameters of the Lloyd and Taylor (1994) Arrhenius-type function:

$R_{\mathrm{eco}}(\mathrm{opt})=R_{\mathrm{ref}} \cdot e^{\left(E_{0}\left(\frac{1}{T_{\mathrm{ref}}-T_{0}}-\frac{1}{T_{\mathrm{s}}-T_{0}}\right)\right)}$

with $R_{\text {eco }}$ in $\mu \mathrm{mol} \mathrm{CO} \mathrm{CO}^{-2} \mathrm{~s}^{-1}$, temperatures in $\mathrm{K}, R_{\text {ref }}$ the ecosystem respiration at the reference temperature $T_{\text {ref }}$ $(=283.15 \mathrm{~K}), T_{0}$ the growth characteristic of the exponential function, and $E_{0}$ an activation energy analogue representing the ecosystem respiration sensitivity to temperature (set to $309 \mathrm{~K}$ ). For the subset of $\mathrm{CO}_{2}$ fluxes measured at WFPS $>75 \%$, the fitted parameters were $R_{\text {ref }}=$ $1.60 \mu \mathrm{mol} \mathrm{CO} \mathrm{C}_{2} \mathrm{~m}^{-2} \mathrm{~s}^{-1}$ and $T_{0}=234 \mathrm{~K}$, and the $R^{2}$ was 0.87 . For drier periods, however, ecosystem respiration was assumed to be limited by the lack of moisture, and $R_{\text {eco }}$ no longer responds to the high summer temperatures as predicted by the Lloyd and Taylor model (e.g. Balogh et al., 2011; Longdoz et al., 2008). We therefore introduced a soil moisture multiplicative term (a sigmoidal function $S$ (WFPS), ranging from 0 to 1 ) to modulate the temperature response:

$$
\begin{aligned}
& R_{\mathrm{eco}}=R_{\mathrm{eco}}(\mathrm{opt}) \cdot S(\mathrm{WFPS}) \\
& \text { with } S(\mathrm{WFPS})=S_{2}+\frac{\left(S_{1}-S_{2}\right)}{1+e^{\left(\frac{\mathrm{WFPS}-S_{3}}{d}\right)}}
\end{aligned}
$$

Here, $S_{2}$ was set to 1 (maximum value for $S$, i.e. no water limitation for $R_{\text {eco }}$ ), and the parameters $S_{1}, S_{3}$ and $d$ were adjusted to maximise the goodness of fit between the observed data and the fluxes predicted by Eq. (8). The resulting values were $S_{1}=0.125, S_{3}=65$ (\% WFPS) and $d=9$ (\% WFPS), with an $R^{2}$ of 0.86 . These numbers suggest $50 \%$ and $80 \%$ reductions of $R_{\text {eco }}$ at WFPS levels of $62 \%$ and $44 \%$, respectively, compared to non water-limiting conditions (Eq. 7).

Note that for the same reason as for $\mathrm{N}_{2} \mathrm{O}$ (see above), the 27th September 2010 datapoint was removed from the data set used to fit parameters of the $\mathrm{CO}_{2}$ algorithm. Also, due to a lack of data points measured in or near waterlogged conditions ( $100 \%$ WFPS), we could not identify whether a reduction in $R_{\text {eco }}$ would actually occur at saturation, due to limited soil $\mathrm{CO}_{2}$ diffusion (Flechard et al., 2007b). However, since waterlogged conditions tend to occur predominantly in the winter half year at this site, when temperatures are low and therefore $R_{\text {eco }}$ is small, the overall (annual) error would likely be small.

Results of temporal $\mathrm{CO}_{2}$ gap-filling using Eq. (8) are presented in Fig. 2c. The semi-empirical model of $R_{\text {eco }}$ reproduces satisfactorily the short-term as well as the seasonal fluctuations observed in system respiration, with summer values severely limited by the lack of moisture, despite the higher temperatures.

Concerning $\mathrm{CH}_{4}$ emissions, no significant relationship between fluxes and environmental conditions was found. Therefore, temporal gap-filling was carried out either with a simple linear interpolation between measurement days (Fig. 2d), or with an average flux multiplied by the duration of the batch as presented in Sect. 2.6.

\subsection{Batch-scale and annual-scale GHG fluxes}

Results of temporal integration for batches WS and SA obtained from the different gap-filling methods described previously are given in Table 4. Emission estimates for $\mathrm{N}_{2} \mathrm{O}$ ranged from 0.86 to $1.01 \mathrm{~kg} \mathrm{~N}_{2} \mathrm{O}-\mathrm{N} \mathrm{ha}^{-1}$ and from 1.45 to $2.44 \mathrm{~kg} \mathrm{~N}_{2} \mathrm{O}-\mathrm{N} \mathrm{ha}^{-1}$ for batches WS and SA, respectively. The run was found to be a net $\mathrm{CH}_{4}$ sink during batch WS $\left(-0.39\right.$ to $\left.-0.34 \mathrm{~kg} \mathrm{CH}_{4}-\mathrm{Cha}^{-1}\right)$ but the flux was probably not significantly different from zero during batch SA ( +0.03 to $\left.+0.07 \mathrm{~kg} \mathrm{CH}_{4}-\mathrm{Cha}^{-1}\right)$. Cumulative estimates of $R_{\text {eco }}$ ranged from +1284 to $+1819 \mathrm{~kg} \mathrm{CO}_{2}-\mathrm{Cha}^{-1}$ during batch WS and from +1560 to $+2312 \mathrm{~kg} \mathrm{CO}_{2}-\mathrm{Cha}^{-1}$ during batch SA, depending on the temporal integration method. For both $\mathrm{N}_{2} \mathrm{O}$ and $\mathrm{CO}_{2}$, the estimates based on the upscaled mean flux and from linear interpolation were systematically higher than estimates using the $T$ - and WFPS-based functions. This is logical since, (i) the distributions of fluxes were not normal but skewed or log-normal, with few elevated (peak) values leading to a bias in average-based estimates, and (ii) fluxes were always measured in the afternoon, when soil temperatures and microbial activity were highest.

Although flux measurements focused on batches WS and SA, and only two flux datapoints are available for batch 4 (Fig. 2), we present tentative estimates of GHG fluxes for batch 4 from 6 May to 31 August 2010 (Table 4), based either on the mean of these two fluxes, or on functional relationships derived from batches WS and SA. Although these values are highly uncertain, we speculate that $\mathrm{N}_{2} \mathrm{O}$ fluxes were rather low due to dry soil conditions and low rainfall during these summer months. These estimates are also needed to provide annual-scale GHG flux estimates, corresponding approximately to the sum of the three batches, and ranging from 2.7 to $4.8 \mathrm{~kg} \mathrm{~N}_{2} \mathrm{O}-\mathrm{N} \mathrm{ha}^{-1} \mathrm{yr}^{-1},-0.5$ to $-0.6 \mathrm{~kg} \mathrm{CH}_{4}-\mathrm{Cha}^{-1} \mathrm{yr}^{-1}$, and 4.4 to $6.1 \mathrm{tCO}_{2}-\mathrm{Cha}^{-1} \mathrm{yr}^{-1}$ ( $R_{\text {eco }}$ only). 
Table 4. GHG fluxes at the batch and annual time scales, using alternative temporal integration methods.

\begin{tabular}{|c|c|c|c|c|c|}
\hline $\begin{array}{l}\text { Integration } \\
\text { period }\end{array}$ & Time interval & $\begin{array}{l}\text { Temporal gap-filling } \\
\text { method }\end{array}$ & $\mathrm{kg} \mathrm{N}_{2} \mathrm{O}-\mathrm{Nha}^{-1}$ & $\mathrm{~kg} \mathrm{CH}_{4}-\mathrm{Cha}^{-1}$ & $\begin{array}{c}\mathrm{kgCO}_{2}-\mathrm{Cha}^{-1} \\
R_{\text {eco }}\end{array}$ \\
\hline \multirow{3}{*}{$\begin{array}{l}\text { Batch } 3 \\
\text { (measured and } \\
\text { gap-filled) }\end{array}$} & \multirow{3}{*}{$\begin{array}{l}13.01 .2010 \text { to } \\
05.05 .2010\end{array}$} & Mean Flux $\cdot N$ days ${ }^{\mathrm{a}}$ & 0.87 & -0.39 & 1569 \\
\hline & & Linear (dot to dot) & 1.01 & -0.34 & 1819 \\
\hline & & Flux $=f\left(T_{\mathrm{s}}, \text { WFPS }\right)^{\mathrm{b}}$ & 0.86 & na & 1284 \\
\hline \multirow{2}{*}{$\begin{array}{l}\text { Batch } 4 \\
\text { (simulation) }\end{array}$} & \multirow{2}{*}{$\begin{array}{l}06.05 .2010 \text { to } \\
31.08 .2010\end{array}$} & Mean Flux $\cdot N$ days $^{\mathrm{a}, \mathrm{c}}$ & 0.84 & -0.61 & 2546 \\
\hline & & Flux $=f\left(T_{\mathrm{s}}, \text { WFPS }\right)^{\mathrm{b}}$ & 0.44 & na & 1469 \\
\hline \multirow{3}{*}{$\begin{array}{l}\text { Batch } 5 \\
\text { (measured and } \\
\text { gap-filled) }\end{array}$} & \multirow{3}{*}{$\begin{array}{l}01.09 .2010 \text { to } \\
05.01 .2011\end{array}$} & Mean Flux $\cdot N$ days ${ }^{\mathrm{a}}$ & 2.44 & 0.03 & 2312 \\
\hline & & Linear (dot to dot) & 2.18 & 0.07 & 2210 \\
\hline & & Flux $=f\left(T_{\mathrm{s}}, \text { WFPS }\right)^{\mathrm{b}, \mathrm{d}}$ & 1.45 & na & 1560 \\
\hline \multirow{3}{*}{$\begin{array}{l}\text { Year } \\
\text { (measured and } \\
\text { gap-filled) }\end{array}$} & \multirow{3}{*}{$\begin{array}{l}01.01 .2010 \text { to } \\
31.12 .2010\end{array}$} & Mean Flux $\cdot N$ days $\mathrm{e}^{\mathrm{e}}$ & 4.76 & -0.46 & 6147 \\
\hline & & Linear (dot to dot) & 3.56 & -0.65 & 5883 \\
\hline & & Flux $=f\left(T_{\mathrm{s}}, \text { WFPS }\right)^{\mathrm{b}}$ & 2.71 & na & 4351 \\
\hline
\end{tabular}

$R_{\text {eco }}=$ Respiration of the (grassland + soil) ecosystem, ${ }^{\text {a }}$ Calculated from the average of all daily fluxes obtained from measurements between the date of first outdoor access of animals (and that of the next batch), ${ }^{\mathrm{b}}$ Measured fluxes + mechanistic gap-filling function (Eq. 5 for $\mathrm{N}_{2} \mathrm{O}-\mathrm{N}$ and Eq. 8 for $\mathrm{CO}_{2}-\mathrm{C}$; not available for $\mathrm{CH}_{4}-\mathrm{C}$ ), ${ }^{\mathrm{c}}$ Based on only two days measurements made after the slaughter of Batch 4., ${ }^{\mathrm{d}}$ For $\mathrm{N}_{2} \mathrm{O}$ and $\mathrm{CO}_{2}$, emission peaks measured on 27.09 .10 added on top of base emission (see text for details),

e Calculated from the average of all daily fluxes obtained from measurements from year start to year end.

\subsection{Magnitude and significance of temporal soil nutrient changes}

Soil nutrient stocks for $\mathrm{C}, \mathrm{N}$ and $\mathrm{P}$ at the paddock scale all increased significantly from start to end of the experiment, as shown in Table S1 (Supplement). The stocks were determined for the $0-15 \mathrm{~cm}$ horizon only, by means of stratified sampling for the $0-5 \mathrm{~cm}$ and $5-15 \mathrm{~cm}$ layers separately, and the data in Table S1 are therefore lower bound estimates of stock changes for the whole soil depth. The paddock-scale stock increments for the $0-15 \mathrm{~cm}$ horizon were $+377 \mathrm{~g} \mathrm{C} \mathrm{m}^{-2} \mathrm{yr}^{-1}\left(+11 \% \mathrm{yr}^{-1}\right), \quad+25 \mathrm{~g} \mathrm{~N} \mathrm{~m}^{-2} \mathrm{yr}^{-1}$ $\left(+7 \% \mathrm{yr}^{-1}\right)$ and $+9 \mathrm{~g} \mathrm{P} \mathrm{m}^{-2} \mathrm{yr}^{-1}\left(+20 \% \mathrm{yr}^{-1}\right)$. Pairedsample t-test statistics on the 25 paired composite samples (initial vs. final) were used since the five soil samples used for each composite sample were extracted from the very same locations $( \pm 10 \mathrm{~cm})$ at the start and end of the experiment. The temporal stock increments were thus statistically highly significant $(P<0.01)$ for all three nutrients.

The main source of uncertainty in the calculation of soil carbon stocks was the evaluation of the fraction of coarse stony elements at the paddock scale, which was of the order of $15 \%$ in the $0-15 \mathrm{~cm}$ layer. We tested the error propagation from the coarse element fraction to the calculated soil elemental stock, and found that hypothetical random errors for the coarse fraction of 5\%,10\% and 30\% would translate into an error (of opposite sign) of $1 \%, 2 \%$ and $5 \%$, approximately, for the soil stock. Given the magnitude of observed changes in C, P and N stocks $(\sim 10-20 \%$ per year), and given that the relevant error is that of the stock change (or difference between two measurements, not that of the absolute stock value at a given time), this study concludes that very significant $\mathrm{C}, \mathrm{N}$ and $\mathrm{P}$ stock changes took place during the experiment.

\section{Discussion}

\subsection{Emission factors for the outdoor run}

There are no measurement-based GHG emission factors (EF) for poultry with outdoor access in the literature. Our flux measurements indicate substantial annual $\mathrm{N}_{2} \mathrm{O}$ emissions and a weak net $\mathrm{CH}_{4}$ sink on the run. For $\mathrm{N}_{2} \mathrm{O}$, the calculation of an $\mathrm{EF}$ requires the knowledge of total $\mathrm{N}$ inputs to the grassland, as well as background $\mathrm{N}_{2} \mathrm{O}$ emissions outside the run, which were provided in our case by three control chambers (Table 2). Note that in this paper, the EF we calculate is based on the total $\mathrm{N}$ input (as in Tier 1 methodology of IPCC), not on a "net" $\mathrm{N}$ input as defined by total input minus $\mathrm{NH}_{3}$ volatilisation (as in Tier 2 methodology of IPCC), which would obviously result in much higher EF values ( $\sim$ factor 2 , if one considers a $50 \% \mathrm{NH}_{3}$ volatilisation/abatement rate).

The only way to quantify $\mathrm{N}$ inputs to the run by broiler droppings is by a calculation of the mass balance of chemical elements in animal feed through the production system (ingestion, retention, excretion), whereby the fraction of outdoor excretion is estimated as the difference between total and indoor excretion. Based on $\mathrm{P}$ and $\mathrm{K}$ data, Meda (2011) showed that the ratios of outdoor/total excretion were $6 \%$ and $47 \%$ for batches WS and SA, respectively, and that excretion of $\mathrm{N}$ on the run was estimated to 5.4 and $42.2 \mathrm{~kg} \mathrm{~N}$ (equivalent to 23 and $180 \mathrm{~kg} \mathrm{Nha}^{-1}$ ) for batches WS and SA, respectively. For batch 4, a similar calculation yielded an outdoor excretion rate of $33.2 \mathrm{~kg} \mathrm{~N}$ 
(equivalent to $141 \mathrm{~kg} \mathrm{Nha}^{-1}$ ), and the annual $\mathrm{N}$ input by outdoor excretion ( 3 batches) to the run was thus estimated at $344 \mathrm{~kg} \mathrm{Nha}^{-1} \mathrm{yr}^{-1}$. This value is high, but according to CORPEN French references (2006), a large part of this $\mathrm{N}$ input is lost through volatilization (60\%), certainly albeit with considerable variability and uncertainty (Sintermann et al., 2011).

Our estimates of annual $\mathrm{N}_{2} \mathrm{O}$ emission range from +2.71 to $+4.76 \mathrm{~kg} \mathrm{~N}_{2} \mathrm{O}-\mathrm{N} \mathrm{ha}^{-1} \mathrm{yr}^{-1}$ for the run (Table 4). The background annual emission for the experimental site, outside the run, calculated as the mean of all control chamber fluxes, was $+1.25 \mathrm{~kg} \mathrm{~N}_{2} \mathrm{O}-\mathrm{N} \mathrm{ha}^{-1} \mathrm{yr}^{-1}$. This background emission is relatively high but can possibly be explained by a high atmospheric $\mathrm{N}$ input $\left(\mathrm{NH}_{3}\right.$ dry deposition from the surrounding experimental farm buildings (poultry, pigs)). The EF for $\mathrm{N}_{2} \mathrm{O}$ is calculated as the run emission minus the background flux, and divided by the excretion $\mathrm{N}$ input. This yields a range of $\mathrm{EF}$ of $0.4 \%$ to $1.0 \%$ for outdoor $\mathrm{N}$ excretion. These values are substantially lower than the IPCC default value of $2 \%$ (IPCC, 2006b). However, our $\mathrm{N}$ input estimate of $344 \mathrm{~kg} \mathrm{Nha}^{-1} \mathrm{yr}^{-1}$ obtained by mass balance calculations was rather high and is also subject to considerable uncertainty.

For $\mathrm{CH}_{4}$, no study on outdoor emissions by free range poultry was found in the literature. However, based on IPCC references (IPCC, 2006a) and on our estimation of droppings partitioning between the house and the run, we calculated a theoretical $\mathrm{CH}_{4} \mathrm{EF}$ of $0.03 \mathrm{~kg} \mathrm{CH}_{4} \mathrm{ha}^{-1} \mathrm{yr}^{-1}$ due to the degradation of organic matter in droppings on the run. This value does not take into account the potential $\mathrm{CH}_{4}$ consumption by the soil microorganisms as frequently observed during our study, with an annual flux of the order of $-0.5 \mathrm{~kg} \mathrm{CH}_{4}-\mathrm{Cha}^{-1} \mathrm{yr}^{-1}$ showing a net sink activity of the grassland. This was at the low end of the range of values reported in the literature (from -1 to $-13 \mathrm{~kg} \mathrm{CH}_{4} \mathrm{ha}^{-1} \mathrm{yr}^{-1}$ ) for non-grazed grasslands (Smith et al., 2000; Castaldi et al., 2007; Klemedtsson et al., 2009), but consistent with those given by Saggar et al. (2008) for New-Zealand pastures $\left(<1 \mathrm{~kg} \mathrm{CH}_{4} \mathrm{ha}^{-1} \mathrm{yr}^{-1}\right)$. Methane oxidation rates are influenced by many factors, many of them related to oxygen availability such as soil water content or porosity. Methane can indeed only be oxidised in specific ranges of moisture when oxygen is available and can diffuse into the soil (Smith et al., 2000; Le Mer and Roger, 2001) though we did not found any significant relationship between average $\mathrm{CH}_{4}$ fluxes and soil moisture (WFPS).

In this study, respiration of the grassland ecosystem $\left(R_{\text {eco }}\right)$ was estimated at $+4351 \mathrm{~kg} \mathrm{CO}_{2}-\mathrm{Cha}^{-1} \mathrm{yr}^{-1}$, and is lower than values reported in the literature for cattle-grazed pastures, ranging from 6400 to more than $15000 \mathrm{~kg} \mathrm{CO}_{2}$ $\mathrm{C} \mathrm{ha}^{-1} \mathrm{yr}^{-1}$ (Allard et al., 2007; Gilmanov et al., 2007). Respiration is known to be influenced by many factors (Jones et al., 2006) such as grassland composition (i.e. species), grassland management (mowing, grazing, fertilization), climatic conditions (temperature, rainfall), soil conditions (wa-
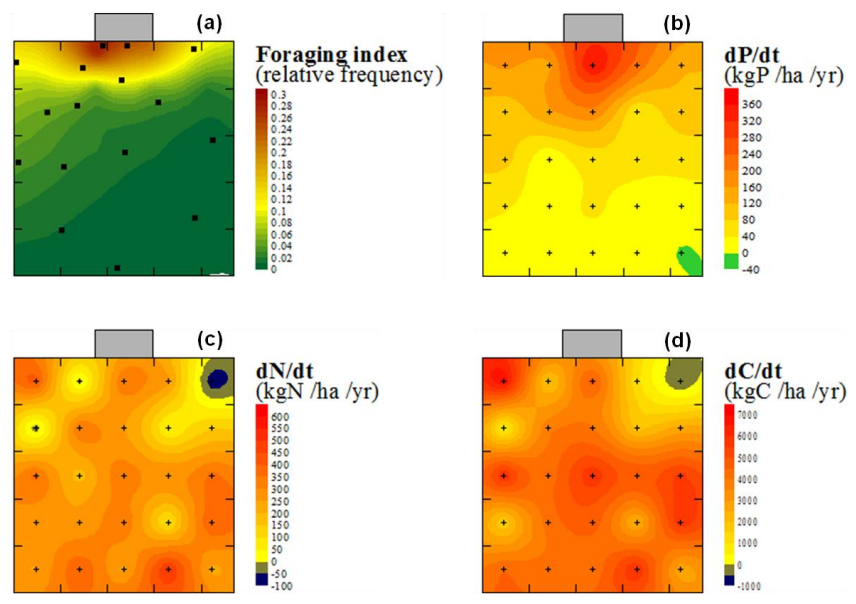

Fig. 6. Kriged maps of broiler foraging index (collective probability of broilers being present on a surface area of $1 \mathrm{~m}^{2}$ at a given location) (a) and annual variations of phosphorus (b), total nitrogen (c) and total carbon (d) soil stocks. Black squares (a) indicate locations for chamber measurements, while crosses $(\mathbf{b}, \mathbf{c}, \mathbf{d})$ indicate soil sampling sites.

ter content, temperature) and gross photosynthetic assimilation rates. The low value of $R_{\text {eco }}$ cannot be explained by limiting conditions in organic matter availability $(\mathrm{C}$ and $\mathrm{N})$ due to the amount brought by droppings. However, soil water was limiting throughout the summer and certainly affected ecosystem respiration as reflected by the need to modulate the temperature response of $R_{\text {eco }}$ by a SWC factor (Eqs. 7 to 9). The mechanism certainly involved a reduction of both autotrophic and heterotrophic components in dry conditions, with limited plant $\mathrm{CO}_{2}$ assimilation rates reducing the supply of root exudates to soil microorganisms.

\subsection{Spatial and temporal controls of GHG fluxes}

The initial distribution of the static chambers on the run was determined under the assumption that broilers would spend more time in the first half of the run, close to the broiler house, where emissions should be higher than in the rest of the run due to a larger amount of nutrients (carbon, nitrogen) excreted. Behavioural observations (Fig. 6a) confirmed indeed that, when they were outdoors, broilers spent most of their time in the first $15 \mathrm{~m}$ of the run $(75 \%$ of the total time spent outdoors), which led to a higher soil accumulation of phosphorus here $(65 \%$ of the total stock increment for the whole run) (Fig. 6b). Similar nutrient accumulation was also reported by Aarnink et al. (2006) and Kratz et al. (2004) who concluded that the phosphorus load in the first meters close to the broiler house was several times higher than Dutch and German standards, respectively, and indicates an enhanced risk of $\mathrm{P}$ run-off, especially in a zone where the plant cover has been suppressed by broilers. Variations in phosphorus soil stock were positively correlated (spatially) 
(a)

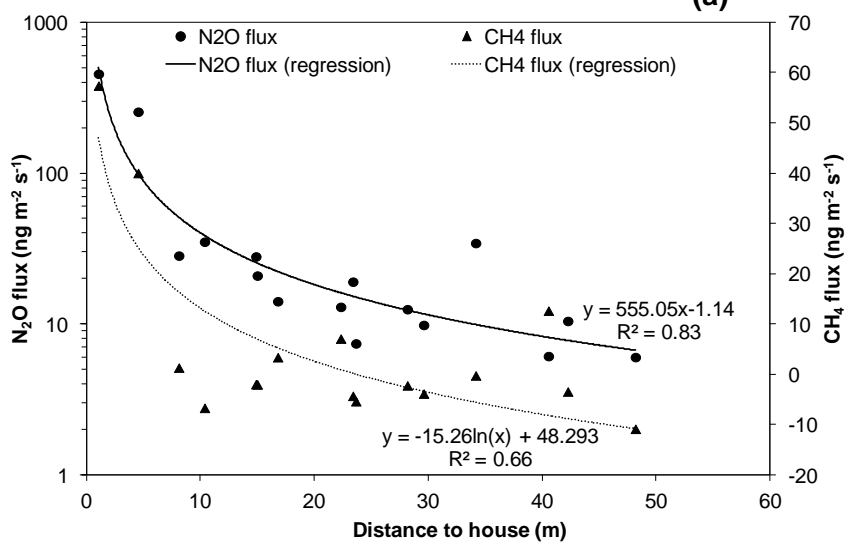

(b)

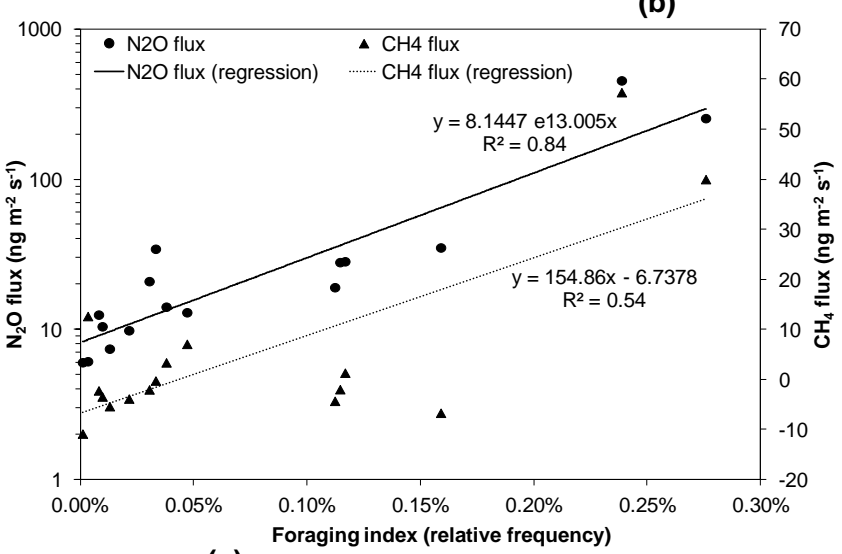

(c)

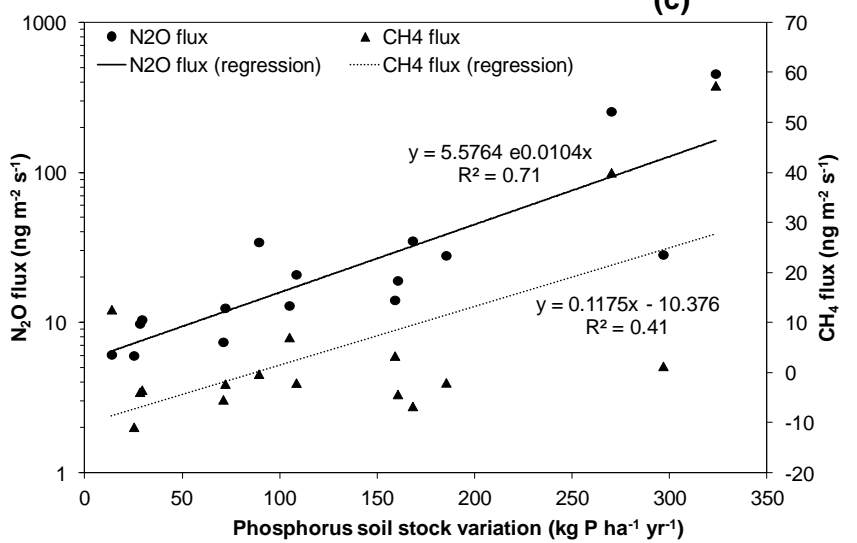

Fig. 7. Relationships between average measured $\mathrm{N}_{2} \mathrm{O}$ and $\mathrm{CH}_{4}$ chamber fluxes and control variables: (a) distance to broiler house. (b) Foraging index. (c) Annual variation of phosphorus soil stock. Each datapoint represents the mean measured flux at one chamber location on the plot.

with the foraging index $\left(R^{2}=0.74\right)$, but no relationship between foraging index and variations in total nitrogen or total carbon soil stocks was found $\left(R^{2}<0.1\right)$. This is due to a faster turnover of carbon and nitrogen than for phosphorus, partly due to the uptake by plants, soil fauna and microorganisms, but more importantly here by mineralisation and gaseous emissions $\left(\mathrm{NH}_{3}, \mathrm{NO}, \mathrm{N}_{2} \mathrm{O}, \mathrm{N}_{2}, \mathrm{CO}_{2}\right)$ in the soil, and possibly leaching $\left(\mathrm{NO}_{3}^{-}\right.$, dissolved inorganic or organic $\mathrm{C}$ and $\mathrm{N}$ ). Further, we may hypothesize that variations in $\mathrm{C}$ and $\mathrm{N}$ soil stocks were of the same magnitude close to the house and at the back of the run because of two distinct phenomena. In the first part of the run, the vegetation was very sparse and the increase in $\mathrm{C}$ and $\mathrm{N}$ in soil was explained by the concentration of nutrients excreted in this zone, whereas at the back of the run, the increase in $\mathrm{C}$ and $\mathrm{N}$ was mostly due to $\mathrm{C}$ sequestration and $\mathrm{N}$ fixation by the soil and the vegetation.

The spatial interpolation of $\mathrm{N}_{2} \mathrm{O}, \mathrm{CH}_{4}$ and $\mathrm{CO}_{2}$ fluxes, summarized in Figs. 3 to 5, respectively, confirmed the dominance of near-house emissions. The highest emission speaks were generally measured in the two chambers placed only one meter away from the pop-holes. Relationships between average measured $\mathrm{N}_{2} \mathrm{O}$ and $\mathrm{CH}_{4}$ fluxes and variations in phosphorus stock soil, foraging index and distance to the broiler house, for all chamber sampling points on the field, are given in Fig. 7. As expected, $\mathrm{N}_{2} \mathrm{O}$ and $\mathrm{CH}_{4}$ fluxes were positively correlated with the animals presence and their cumulative droppings (as shown by the increase in soil P), and negatively correlated with distance to the broiler house. Good correlation between $\mathrm{CO}_{2}$ fluxes and these variables (not shown in this paper) was also found $\left(R^{2}>0.50\right)$.

The spatial variability of fluxes and the higher emissions measured in the first $15 \mathrm{~m}$ of the run could be explained by the amount of carbon and nitrogen available for soil microorganisms. We may assume that the high amount of nutrients excreted close to the house generated a non-limiting situation for soil microbial activity (Flechard et al., 2005), which, coupled with the disappearance of the plant cover in the first meters in front of the broiler house, because of broiler consumption, stalling and compaction, led to the absence of competition for resources for soil microorganisms. This indicates that $R_{\text {eco }}$ was dominated by soil heterotrophic respiration. Furthermore, the surface compaction of the soil in the first meters of the run (Fig. 1), coupled with high input of reactive 
$\mathrm{C}$, may have generated local anaerobic conditions and thus enhanced the production of $\mathrm{N}_{2} \mathrm{O}$ through denitrification and $\mathrm{CH}_{4}$ production. By the same token, this compaction certainly reduced oxygen availability in the soil and thus limited methane oxidation. The large amounts of $\mathrm{N}$ dropped in this zone could also have limited the potential for $\mathrm{CH}_{4}$ oxidation and increased $\mathrm{N}_{2} \mathrm{O}$ emission by microorganisms through the increased oxidation of ammonium into nitrite (nitrification) by the same enzyme (methane monooxygenase) as reported in the literature (Le Mer and Roger, 2001; Jassal et al., 2011).

$\mathrm{N}_{2} \mathrm{O}$ emission is known to respond to soil $\mathrm{pH}$, but the effect is complex. The rates of both nitrification and denitrification increase with $\mathrm{pH}$ from acidic conditions ( $\mathrm{pH} 3$ to 5) to slightly alkaline soils. However, for $\mathrm{N}_{2} \mathrm{O}$ emissions conflicting results have been reported, with a positive impact of $\mathrm{H}^{+}$on $\mathrm{N}_{2} \mathrm{O}$ emissions in acidic soils, if denitrification is the main source, and a negative impact of $\mathrm{H}^{+}$on emissions in near-neutral to slightly alkaline conditions, if nitrification is the main source (Granli and Bøckman, 1994). The slightly alkaline soil $\mathrm{pH}$ at this site (8.1) might suggest a dominant role of nitrification. On the other hand, the change in $\mathrm{pH}$ from start to end of this experiment was only of the order of $-0.1 \mathrm{pH}$ units, and no significant spatial variability in $\mathrm{pH}$ was observed in response to the differential loads of organic matter and $\mathrm{N}$ across the paddock, due to the strong stability and buffer provided by the high calcium carbonate content $(20 \%)$.

The effect of run characteristics and season on broiler behaviour has been studied in the literature. It is commonly accepted that the foraging of free-range poultry increases with better climatic conditions (warmer temperature for instance) and with the presence on the run of "vertical structural elements" (trees, bushes), because they provide shade and shelters from predators and snow or rain (Haneklaus et al., 2000; Cornetto and Estevez, 2001; Lubac et al., 2003; Zeltner and Hirt, 2003, 2008; Hegelund et al., 2005; Germain et al., 2010, 2011). The presence on the run of a number of vertical elements such as trees could therefore lead to a better spatial distribution of droppings, reducing the occurrence of emission (gaseous, leaching) hotspots, limit the risks of vegetation degradation close to the house and improve the general functioning of the ecosystem (e.g. Fig. 1), which would thus absorb a greater fraction of the excess nutrients deposited. In these conditions, we suggest that plot-scale levels of emission should be lower in runs planted with trees and bushes than those we measured in this study. Further experiments are required to confirm this hypothesis.

The temporal variability of fluxes was mainly due to seasonal changes in soil moisture (WFPS) and temperature. Since fluxes were measured in a large range of WFPS (30$100 \%)$ and temperature $\left(0-30^{\circ} \mathrm{C}\right)$, we may reasonably think that the uncertainty of our annual estimates of $\mathrm{N}_{2} \mathrm{O}$ and $\mathrm{CO}_{2}$ fluxes based on gap-filling functions is moderate. A part of the uncertainty in our estimates stems from the fact that environmental variables were measured outside the run and that the same value of WFPS and temperature were used for the whole field, while measurements and observations all indicate large heterogeneity in density of the plant cover (leaf area index) and soil characteristics. The slope of the run (Fig. 1) probably also induced a higher SWC close to the broiler house (Fig. 1) than upslope, due to surface run-off, especially during high intensity precipitation events. Therefore, local predictions of $T$ and SWC would reduce uncertainty of annual averages of GHG fluxes from the run.

\subsection{Towards a net GHG budget of the outdoor run}

Emission factors are needed from an inventory viewpoint (IPCC), but to assess the whole climate change impact of a production system, a total net GHG exchange (NGHGE), taking into account all global warming potential (GWP) contributions by $\mathrm{CO}_{2}, \mathrm{~N}_{2} \mathrm{O}$ and $\mathrm{CH}_{4}$ fluxes is required (Soussana et al., 2007). In this study we determined the net $\mathrm{N}_{2} \mathrm{O}$ and $\mathrm{CH}_{4}$ fluxes, but for $\mathrm{CO}_{2}$ only ecosystem respiration $\left(R_{\text {eco }}\right)$ was measured; for a full GHG balance at the paddock scale, the net ecosystem exchange (NEE, measurable by eddy covariance, see e.g. Ammann et al., 2007), defined as gross primary production (GPP) minus $R_{\mathrm{eco}}$, would be required. In addition, $\mathrm{CO}_{2}$ losses by animal respiration $\left(R_{\text {broilers }}\right)$ would add to emissions by plants and soil, as would losses by soil dissolved organic and inorganic carbon leaching, as well as exports by animals as they consume worms and other forms of terrestrial organic materials. C imports by animal excreta on the other hand contribute very significantly to an increase in soil organic matter in this system.

In the absence of measurements for many of these terms, we derived a tentative net GHG budget by inferring NEE from the observed and significant change in soil organic carbon $\left(+377 \mathrm{~g} \mathrm{C} \mathrm{m}^{-2} \mathrm{~s}^{-1}\right.$, see Sect. 3.5) and by making various assumptions concerning $\mathrm{C}$ imports, $\mathrm{C}$ exports and $\mathrm{C}$ leaching. The details of the methodology and reference values from the literature used for this calculation are provided in the Supplement. The NEE estimate for the grassland + broiler system $\left(\mathrm{NEE}_{\mathrm{G}+\mathrm{B}}\right)$ thus obtained was $-1163 \mathrm{~kg} \mathrm{Cha}^{-1} \mathrm{yr}^{-1}$, implying that the whole ecosystem (soil + vegetation + animals) would have been a net $\mathrm{C}$ sink, which was offset by roughly one third by $\mathrm{N}_{2} \mathrm{O}$ emissions with a negligible impact by $\mathrm{CH}_{4}$ oxidation. Overall, the NGHGE of $-2561 \mathrm{~kg} \mathrm{CO}_{2}$ eq. ha ${ }^{-1} \mathrm{yr}^{-1}$ would suggest that the outdoor part of the rearing system behaves as a net sink of greenhouse gases, but it must be stressed that uncertainties are very large and plot-scale measurements of all component terms are required to provide a more reliable and robust estimate. In addition, much of the short-term $(\sim 2$-yr $)$ increase in soil organic carbon was likely contributed by deposited bird excreta, the longer term fate of which is uncertain, and which therefore does not necessarily represent a potential for C sequestration. 


\section{Conclusions}

Annual GHG flux estimates suggest that the run of organic, free-range broilers emitted between 2.7 and $4.7 \mathrm{~kg} \mathrm{~N}_{2} \mathrm{O} \mathrm{ha}^{-1} \mathrm{yr}^{-1}$ and acted as a very weak sink of $\mathrm{CH}_{4}$, which compensated less than $1.5 \%$ of the $\mathrm{N}_{2} \mathrm{O}$ forcing effect. Spatial variability of fluxes was high. As expected, GHG fluxes were higher close to the broiler house where large amounts of organic matter are excreted by the broilers. The temporal variability of fluxes is related to soil moisture and temperature, which regulate soil microbial processes. The uncertainty associated with our estimates can be reduced by an improved understanding and modelling of processes controlling GHG fluxes. This study provides the first measurement-based assessment of outdoor $\mathrm{N}_{2} \mathrm{O}$ emissions factors for "grazing" poultry. However, this value is sitespecific and more measurements are needed in different climatic conditions and over different soil and vegetation types, in order to derive a comprehensive and representative set of values to be used in emission inventories and in Life Cycle Assessment approaches. Based on measured GHG fluxes and on the change of soil organic carbon during the time frame of the experiment, we calculated a short-term net GHG budget for the run, equivalent to a net sink of $-2600 \mathrm{~kg} \mathrm{CO}_{2}$ equivalent $\mathrm{ha}^{-1} \mathrm{yr}^{-1}$. However, more data over the lifetime of a production system (e.g. $10 \mathrm{yr}$ ) would be required to assess the long term soil carbon sequestration potential. This study focused on GHG fluxes, and outdoor ammonia emissions should be also quantified, given the potential impacts associated to ammonia deposition downwind from the source (eutrophication, acidification, secondary $\mathrm{N}_{2} \mathrm{O}$ emissions).

\section{Supplementary material related to this article is available online at: http://www.biogeosciences.net/9/ 1493/2012/bg-9-1493-2012-supplement.pdf.}

Acknowledgements. This work was funded by the research program "Pour et Sur le Développement Régional dans le Grand Ouest" and carried out in the framework of the ALTERAVIBIO project. We are thankful to Sylvain Busnot, Gilles Dutin, Marcel Lecomte, Jean-Christophe Gamain, Dimitri Mancion, Eddie Lamothe, Serge Ollivier, Thierry Souche, Renaud Pouget, and Nicole Milcent who carried out the chamber measurements, behavioural observations and soil sampling. We are thankful to Christine Leterrier who helped us with the processing of the behavioural data. We also wish to thank Sylvie Picard and IRSTEA for the use of the gas chromatograph and Michel Burban who built the chambers. The authors gratefully acknowledge Albrecht Neftel for his advice and comments on this paper.

Edited by: S. Reis

\section{References}

Aarnink, A. J. A., Hol, J. M. G., and Beurskens, A. G. C.: Ammonia emission and nutrient load in outdoor runs of laying hens, Wageningen Journal of Life Sciences, 54, 223-234, 2006.

Allard, V., Soussana, J.-F., Falcimagne, R., P. Berbigier, P., Bonnefond, J.-M., Ceschia, E., D’hour, P., Hénault, C., Laville, P., Martin, C., and Pinarès-Patino, C.: The role of grazing management for the net biome productivity and greenhouse gas budget $\left(\mathrm{CO}_{2}, \mathrm{~N}_{2} \mathrm{O}\right.$ and $\left.\mathrm{CH}_{4}\right)$ of semi-natural grassland, Agr. Ecosyst. Environ., 121, 47-58, 2007.

Amman, C., Flechard, C. R., Leifeld, J., Neftel, A., and Fuhrer, J.: The carbon budget of newly established temperate grassland depends on management intensity, Agr. Ecosyst. Environ., 121, 5-20, 2007.

Balogh, J., Pinter, K., Foti, S., Cserhalmi, D., Papp, M., and Nagy, Z.: Dependence of soil respiration on soil moisture, clay content, soil organic matter, and $\mathrm{CO}_{2}$ uptake in dry grasslands, Soil Biol. Biochem., 43, 1006-1013, 2011.

Castaldi, S., Costantini, M., Cenciarelli, P., Ciccioli, P., and Valentini, R.: The methane sink associated to soils of natural and agricultural ecosystems in Italy, Chemosphere, 66, 723-729, 2007.

Conen, F. and Smith, K. A.: A re-examination of closed flux chamber methods for the measurement of trace gas emissions from soils to the atmosphere, Eur. J. Soil Sci., 49, 701-707, 1998.

Cornetto, T. and Estevez, I.: Influence of vertical panels on use of space by domestic fowl, Appl. Anim. Behav. Sci., 71, 141-153, 2001.

CORPEN: Estimation des rejets d'azote, phosphore, potassium, calcium, cuivre, zinc par les élevages avicoles, Comité d'Orientation pour des Pratiques Agricoles Respectueuses de l'Environnement, 55 pp., 2006.

Davidson, E. A.: Fluxes of nitrous oxide and nitric oxide from terrestrial ecosystems, in: Microbial production and consumption of greenhouse gases: methane, nitrogen oxide and halomethanes, edited by: Rogers, J. E. and Whitman, W. B., American Society for Microbiology, Washington, DC, 219-235, 1991.

FAO: Livestock long shadow, Environmental issues and options, FAO, Rome, Italy, 390 pp., 2006.

Flechard, C. R., Neftel, A., Jocher, M., Ammann, C., and Fuhrer, J.: Bi-directional soil/atmosphere $\mathrm{N}_{2} \mathrm{O}$ exchange over two mown grassland systems with contrasting management practices, Glob. Change Biol., 11, 2114-2127, 2005.

Flechard, C. R., Ambus, P., Skiba, U., Rees, R. M., Hensen, A., van Amstel, A., van den Pol-van Dasselaar, A., Soussana, J.-F., Jones, M., Clifton-Brown, J., Raschi, A., Horvath, L., Neftel, A., Jocher, M., Ammann, C., Leifeld, J., Fuhrer, J., Calanca, P., Thalman, E., Pilegaard, K., DiMarco, C., Campbell, C., Nemitz, E., Hargreaves, K. J., Levy, P. E., Ball, B. C., Jones, S. K., van de Bulk, W. C. M., Groot, T., Blom, M., Domingues, R., Kasper, G., Allard, V., Ceschia, E., Cellier, P., Laville, P., Henault, C., Bizouard, F., Abdalla, M., Williams, M., Baronti, S., Berretti, F., and Grosz, B.: Effects of climate and management intensity on nitrous oxide emissions in grassland systems across Europe, Agr. Ecosyst. Environ., 121, 135-152, 2007a.

Flechard, C. R., Neftel, A., Jocher, M., Ammann, C., and Leifeld, J.: Temporal changes in soil pore space $\mathrm{CO}_{2}$ concentration and storage under permanent grassland, Agr. Forest Meteorol., 142, 66-84, 2007b. 
Gac, A., Beline, F., Bioteau, T., and Maguet, K.: A French inventory of gaseous emissions $\left(\mathrm{CH}_{4}, \mathrm{~N}_{2} \mathrm{O}, \mathrm{NH}_{3}\right)$ from livestock manure management using a mass-flow approach, Livest. Sci., 112, 252 260, 2007.

Germain, K., Simonet, P., Leterrier, C., Juin, H., and Guemene, D.: Individual variability in exploratory behaviour in organic broiler production, XIIIth European Poultry Conference, Tours, France, p. 900, 2010.

Germain, K., Parou, P., Chapuis, H., Pouget, R., Juin, H., Guéméné, D., and Leterrier, C.: Des pistes pour améliorer l'utilisation du parcours chez les poulets de chair biologique, 9èmes Journées de la Recherche Avicole, Tours, France, 96-100, 2011.

Gilmanov, T. G., Soussana, J. F., Aires, L., Allard, V., Ammann, C., Balzarolo, M., Barcza, Z., Bernhofer, C., Campbell, C. L., Cernusca, A., Cescatti, A., Clifton-Brown, J., Dirks, B. O. M., Dore, S., Eugster, W., Fuhrer, J., Gimeno, C., Gruenwald, T., Haszpra, L., Hensen, A., Ibrom, A., Jacobs, A. F. G., Jones, M. B., Lanigan, G., Laurila, T., Lohila, A., G.Manca, Marcolla, B., Nagy, Z., Pilegaard, K., Pinter, K., Pio, C., Raschi, A., Rogiers, N., Sanz, M. J., Stefani, P., Sutton, M., Tuba, Z., Valentini, R., Williams, M. L., and Wohlfahrt, G.: Partitioning European grassland net ecosystem $\mathrm{CO}_{2}$ exchange into gross primary productivity and ecosystem respiration using light response function analysis, Agr. Ecosyst. Environ., 121, 93-120, 2007.

Granli, T. and Bøckman, O. C.: Nitrous oxide from agriculture, Norwegian J. Agr. Sci., Supplement, 12, 1-128, 1994.

Haneklaus, S., Schnug, E., and Berk, J.: Small-scale spatial variability of phosphorus in soil and its relationship to animal behavior, 5th International Conference on Precision Agriculture, Bloomington, Minnesota, USA, 1-12, 2000.

Hegelund, L., Sørensen, J. T., Kjær, J. B., and Kristensen, I. S.: Use of the range area in organic egg production systems: effect of climatic factors, flock size, age and artificial cover, Brit. Poultry Sci., 46, 1-8, 2005.

International Organization for Standardization (ISO): ISO 11263: Spectrometric determination of phosphorus soluble in sodium hydrogen carbonate solution, 5 pp., 1994.

International Organization for Standardization (ISO): ISO 10694: Determination of organic and total carbon after dry combustion, 7 pp., 1995.

International Organization for Standardization (ISO): ISO 13878: Determination of total nitrogen content by dry combustion, $5 \mathrm{pp}$., 1998.

IPCC: 2006 IPCC Guidelines for national greenhouse gas inventories - Chapter 10: Emissions from livestock and manure management, Intergovernmental Panel on Climate Change, 87 pp., $2006 \mathrm{a}$.

IPCC: 2006 IPCC Guidelines for national greenhouse gas inventories - Chapter 11: $\mathrm{N}_{2} \mathrm{O}$ emissions from managed soils, and $\mathrm{CO}_{2}$ emissions from lime and urea application, Intergovernmental Panel on Climate Change, 54 pp., 2006b.

IPCC: Climate Change 2007: Synthesis Report, Intergovernmental Panel on Climate Change, 52 pp., 2007a.

IPCC: Climat Change 2007: The Physical Science Basis. Chapter 2: Changes in Atmospheric Constituents and in Radiative Forcing, Intergovernmental Panel on Climate Change, 129-234, $2007 \mathrm{~b}$.

Jassal, R. S., Black, T. A., Roy, R., and Ehtier, G.: Effect of nitrogen fertilization on soil $\mathrm{CH}_{4}$ and $\mathrm{N}_{2} \mathrm{O}$ fluxes, and soil and bole respiration, Geoderma, 162, 182-186, 2011.
Jones, S. K., Rees, R. M., Kosmas, D., Ball, B. C., and Skiba, U.: Carbon sequestration in a temperate grassland, Soil Use Manage., 22, 132-142, 2006.

Klemedtsson, A. K., Weslien, P., and Klemedtsson, L.: Methane and nitrous oxide fluxes from a farmed Swedish Histosol, Eur. J. Soil Sci., 60, 321-331, 2009.

Kratz, S., Rogasik, J., and Schnug, E.: Changes in soil nitrogen and phosphorus under different broiler production systems, J. Environ. Qual., 33, 1662-1674, 2004.

Le Mer, J. and Roger, P.: Production, oxidation, emissions and consumption of methane by soils: A review, Eur. J. Soil Biol., 37, 25-50, 2001

Levy, P. E., Gray, A., Leeson, S. R., Gaiawyn, J., Kelly, M. P. C., Cooper, M. D. A., Dinsmore, K. J., Jones, S. K., and Sheppard, L. J.: Quantification of uncertainty in trace gas fluxes measured by the static chamber method, Eur. J. Soil Sci., 62, 811-821, 2011.

Lloyd, J., and Taylor, J. A.: On the temperature dependence of soil respiration, Funct. Ecol., 8, 315-323, 1994.

Longdoz, B., Gross, P., and Granier, A.: Multiple quality tests for analysing $\mathrm{CO}_{2}$ fluxes in a beech temperate forest, Biogeosciences, 5, 719-729, doi:10.5194/bg-5-719-2008, 2008.

Lubac, S., Senecaille, M., Spérandio, D., Desquennes, A., Arnould, C., Faure, J. M., and Mirabito, L.: Influence de la présence de taillis de saule à très courte rotation sur la fréquentation des parcours par les poulets Label, Cinquièmes Journées de la Recherche Avicole Tours, France, 77-80, 2003.

Meda, B.: Une approche dynamique des flux d'éléments et d'énergie des ateliers de production avicole avec ou sans parcours: Conception et application du modèle MOLDAVI, Ph.D. thesis, Agrocampus Ouest, France, 238 pp., 2011.

Meda, B., Hassouna, M., Aubert, C., Robin, P., and Dourmad, J. Y.: Influence of rearing conditions and manure management practices on ammonia and greenhouse gas emissions from poultry houses, World Poultry Sci. J., 67, 441-456, 2011.

Monteith, J. L.: Evaporation and the environment, Symposium of the Society of Exploratory Biology, 19, 205-234, 1965.

Norman, J. M. and Campbell, G.: Application of a plant environment model to problems in the environment, Adv. Irrig., 2, 155188,1983

Pain, B. and Menzi, H.: RAMIRAN Glossary of terms on livestock and manure management 2011, second Edn., 80 pp., 2011.

Ravishankara, A. R., Daniel, J. S., and W. Portmann, R. W.: Nitrous oxide $\left(\mathrm{N}_{2} \mathrm{O}\right)$ : The dominant ozone-depleting substance emitted in the 21st century, Science, 326, 123-125, 2009.

Saggar, S., Tate, K. R., Giltrap, D. L., and Singh, J.: Soilatmosphere exchange of nitrous oxide and methane in New Zeland terrestrial ecosystems and their mitigation options: a review, Plant Soil, 309, 25-42, 2008.

Sintermann, J., Neftel, A., Ammann, C., Häni, C., Hensen, A., Loubet, B., and Flechard, C. R.: Are ammonia emissions from fieldapplied slurry substantially over-estimated in European emission inventories?, Biogeosciences Discuss., 8, 10069-10118, doi:10.5194/bgd-8-10069-2011, 2011

Smith, K. A., Clayton, H., McTaggart, I. P., Thomson, P. E., Arah, J. R. M., and Scott, A.: The measurement of nitrous oxide emissions from soil by using chambers, Philos. T. Roy. Soc. A., 351, 327-337, 1995.

Smith, K. A., Dobbie, K. E., Ball, B. C., Bakken, L. R., Sitaula, B. K., Hansen, S., Brumme, R., Borken, W., Christensen, S., 
Priemé, A., Fowler, D., Macdonald, J. A., Skiba, U., Klemedtsson, L., Kasimir-Klemedtsson, A., Degorska, A., and Orlanski, P.: Oxidation of atmospheric methane in Northern European soils, comparison with other ecosystems, and uncertainties in the global terrestrial sink, Glob. Change Biol., 6, 791-803, 2000.

Smith, K. A., Ball, T., Conen, F., Dobbie, K. E., Massheder, J., and Rey, A.: Exchange of greenhouse gases between soil and atmosphere: interactions of soil physical factors and biological processes, Eur. J. Soil Sci., 54, 779-791, 2003.

Soussana, J.-F., Allard, V., Pilegaard, K., Ambus, P., Amman, C., Campbell, C., Ceschia, E., Clifton-Brown, J., Czobel, S., Domingues, R., Flechard, C., Fuhrer, J., Hensen, A., Horvath, L., Jones, M., Kasper, G., Martin, C., Nagy, Z., Neftel, A., Raschi, A., Baronti, S., Rees, R. M., Skiba, U., Stefani, P., Manca, G., Sutton, M., Tuba, Z., and Valentini, R.: Full accounting of the greehouse gas $\left(\mathrm{CO}_{2}, \mathrm{~N}_{2} \mathrm{O}, \mathrm{CH}_{4}\right)$ budget of nine European grassland sites, Agr. Ecosyst. Environ., 121, 121-134, 2007.
UNFCCC: Copenhagen Accord, United Nations Framework Convention on Climate Change, Copenhagen, 5 pp., 2009.

Zeltner, E. and Hirt, H.: Effect of artificial structuring on the use of laying hen runs in a free-range system, Brit. Poultry Sci., 44, 533-537, 2003.

Zeltner, E. and Hirt, H.: Factors involved in the improvement of the use of hen runs, Appl. Anim. Behav. Sci., 114, 395-408, 2008. 